DOE/EIA-0546(98)

Energy Gducation

Kindergarten through 12th Grade Kindergarten through

September 1998

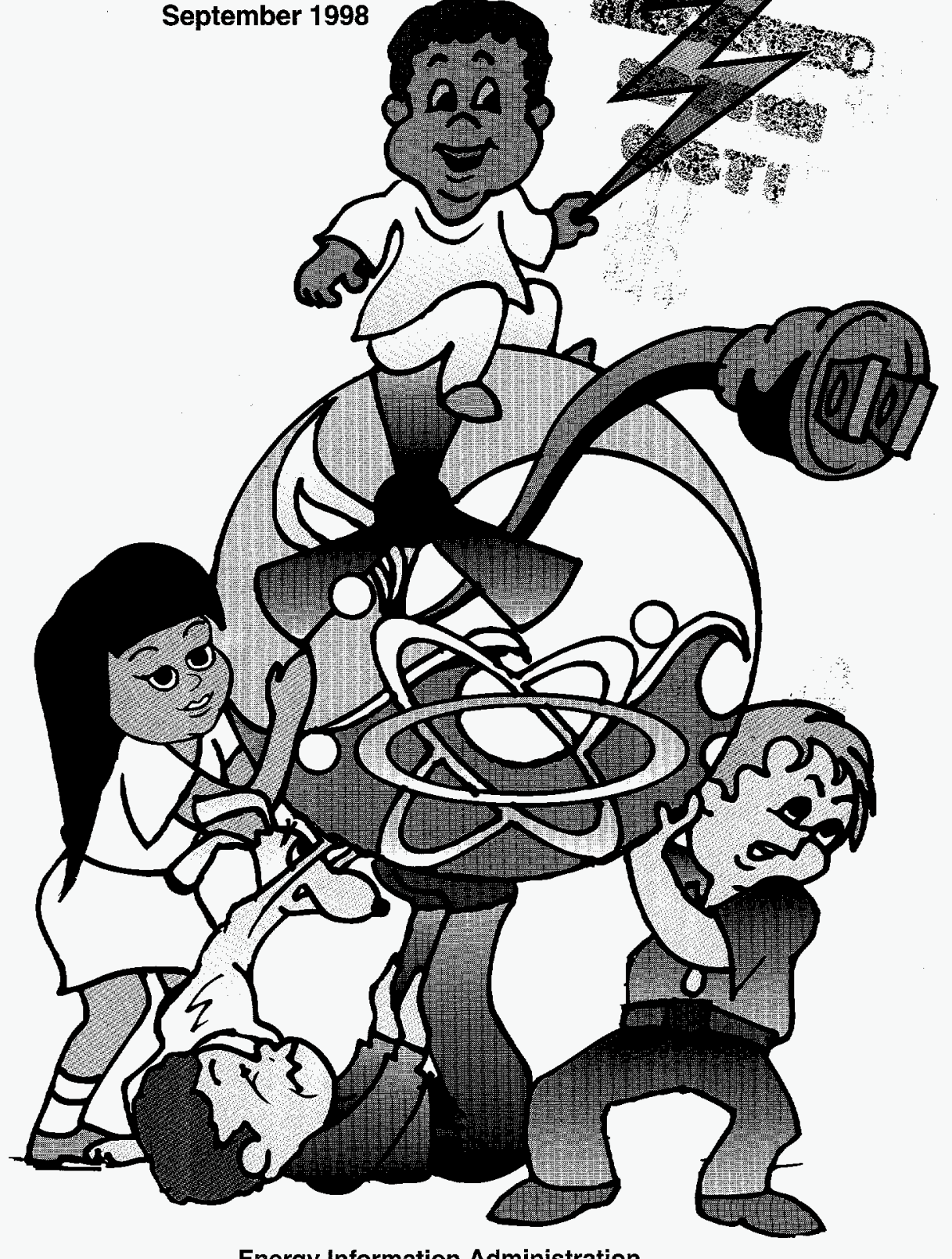

Energy Information Administration

National Energy Information Center

U.S. Department of Energy

Washington, D.C. 20585 


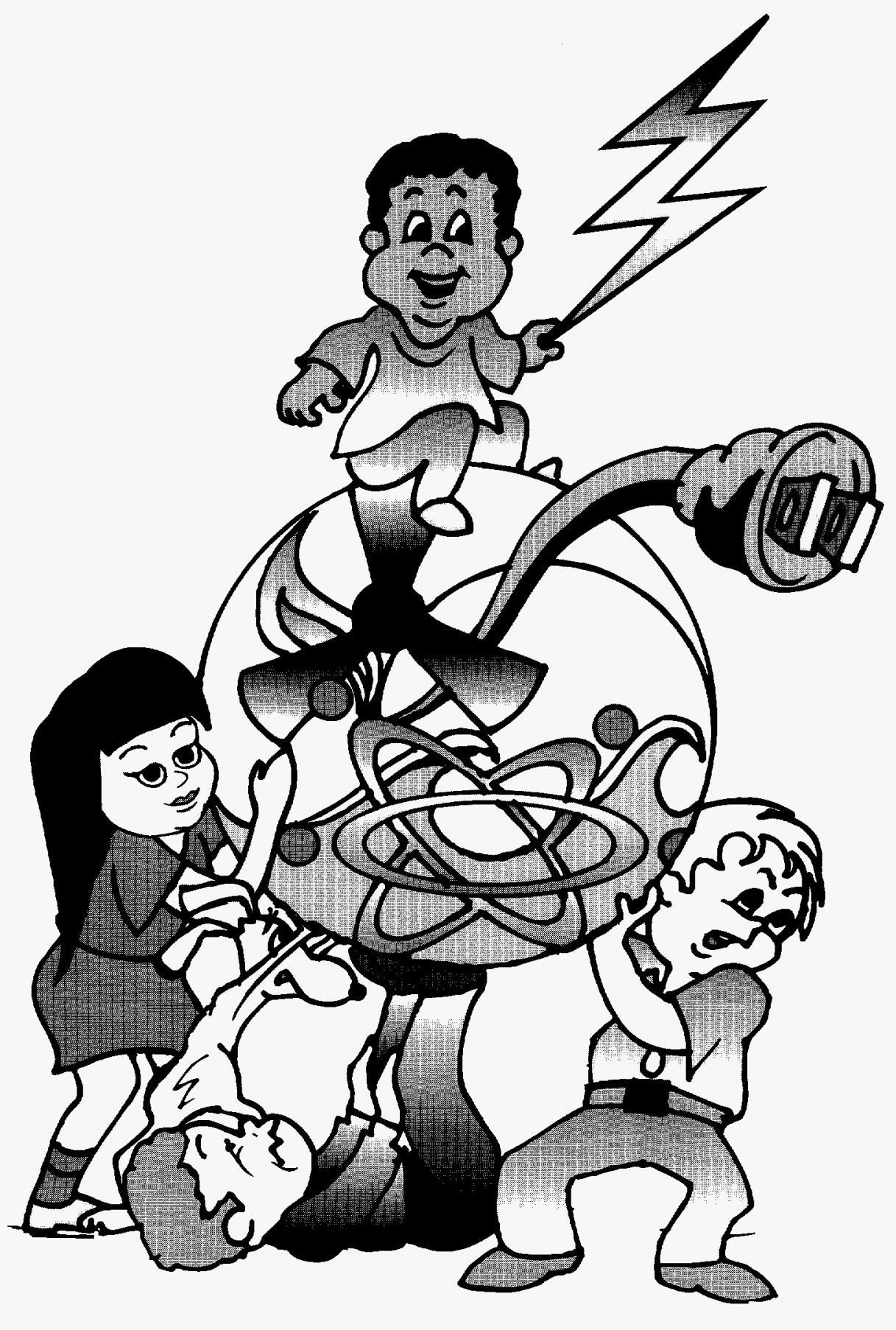




\section{MOESED PREFACE SEP 251998}

Energy Education Resources: Kindergarten Through th Grade is published by the National Energy Information Center (NEIC, iner ice of the Energy Information Administration (EIA), to provide students, educators, and other information users, a list of generally available free or low-cost energy-related educational materials.

Each entry includes the address, telephone number, and description of the organization and the energy-related materials available. Most of the entries also include Internet (Web) and electronic mail (E-Mail) addresses. Each entry is followed by a number, which is referenced in the subject index in the back of this book.

Some of the organizations represented in this list take policy positions on certain energy issues and express them even in educational materials. Because EIA is the independent statistical and analytical agency within the U.S. Department of Energy (DOE), it does not advocate any policy position of DOE or any other organization. EIA has completed this list solely to aid educators and students in locating materials.

Paula Altman of NEIC updates and compiles Energy Education Resources once a year. To include a new entry, contact NEIC at the following address:

National Energy Information Center, EI-30

Energy Information Administration

Room 1F-048, Forrestal Building

1000 Independence Avenue, S.W.

Washington, DC 20585

(202) $586-8800$ ( 9 a.m. to 5 p.m., Eastern time, M-F)

E-Mail: infoctr@eia.doe.gov

Copies of this publication are available free of charge from NEIC. It is also available on EIA's World Wide Web site: www.eia.doe.gov.

Released for Printing: September 2, 1998

Q8)

Printed with soy ink on recycled paper

DISTRBBTION OF THIS DOCUMENT IS UNUMUTED \& MASTER 


\section{CONTENTS}

Air \& Waste Management Association (A\&WMA) $\ldots \ldots \ldots \ldots \ldots \ldots 1$

2 The Alliance to Save Energy . . . . . . . . . . . . . . . . . . . . 1

3 The Aluminum Association, Inc. . . . . . . . . . . . . . . 2

4 American Association for Vocational Instructional Materials . . . . . . . 2

5 American Chemical Society $\ldots \ldots \ldots \ldots \ldots \ldots \ldots \ldots \ldots \ldots \ldots \ldots \ldots$

6 American Coal Foundation $\ldots \ldots \ldots \ldots \ldots \ldots \ldots \ldots \ldots \ldots \ldots \ldots \ldots \ldots \ldots$

7 American Council for an Energy-Efficient Economy (ACEEE) . . . . . . 3

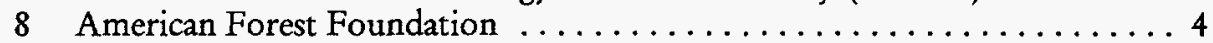

9 American Geological Institute (AGI) $\ldots \ldots \ldots \ldots \ldots \ldots \ldots \ldots \ldots$

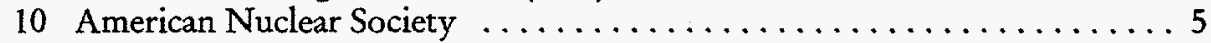

11 American Petroleum Institute $\ldots \ldots \ldots \ldots \ldots \ldots \ldots \ldots \ldots \ldots \ldots$

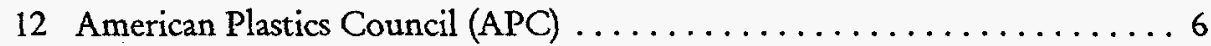

13 American Public Power Association $\ldots \ldots \ldots \ldots \ldots \ldots \ldots \ldots \ldots$

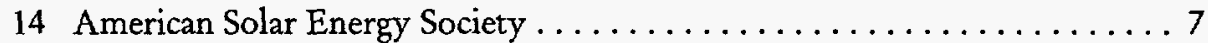

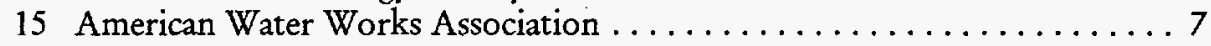

16 American Wind Energy Association $\ldots \ldots \ldots \ldots \ldots \ldots \ldots \ldots \ldots$

17 Apple Computer, Inc. . . . . . . . . . . . . . . . . . . 8

18 Arizona Department of Commerce $\ldots \ldots \ldots \ldots \ldots \ldots \ldots \ldots \ldots$

19 The Aseptic Packaging Council $\ldots \ldots \ldots \ldots \ldots \ldots \ldots \ldots \ldots \ldots$

20 The Bakken Library and Museum $\ldots \ldots \ldots \ldots \ldots \ldots \ldots \ldots \ldots$

21 Baltimore Gas and Electric Company (BGE) $\ldots \ldots \ldots \ldots \ldots \ldots \ldots$

22 BP America ................................. 11

23 Bronx Zoo/Wildlife Conservation Park ................... 11

24 Bullfrog Films ............................. 12

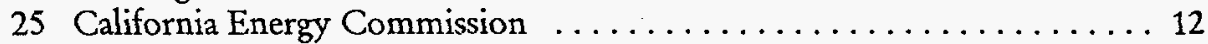

26 California Foundation for Agriculture in the Classroom . . . . . . . . 13

27 The Center for Energy and Economic Development (CEED) . . . . . . 14

28 Center for Renewable Energy and Sustainable Technology (CREST) . . . 14

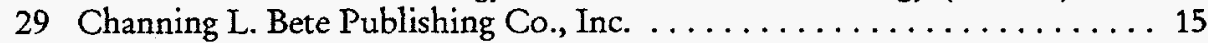

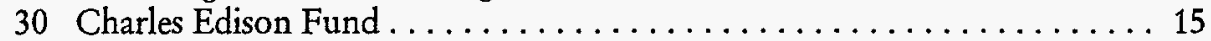

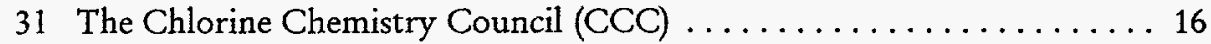

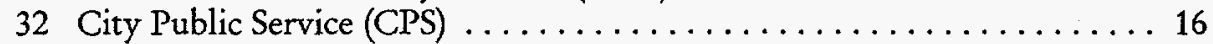

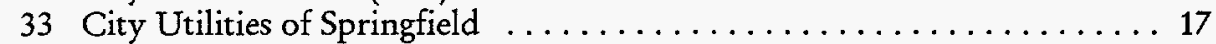

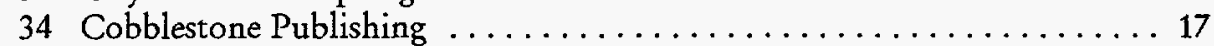

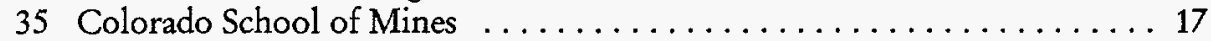

36 The Consumer Aerosol Products Council $\ldots \ldots \ldots \ldots \ldots \ldots \ldots \ldots$

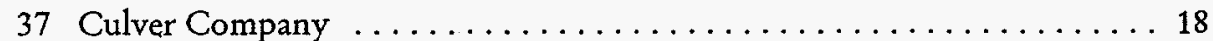

38 Dayton Power \& Light Company . . . . . . . . . . . . . . . 19

39 Denver Earth Science Project ........................ 19 


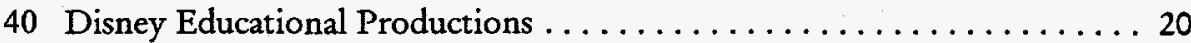

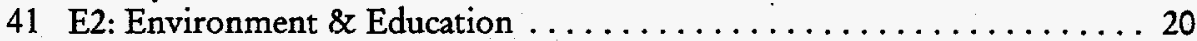

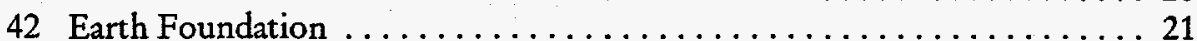

43 East Ohio Gas ................................ 21

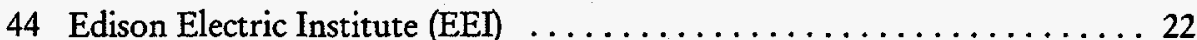

45 Edison Plaza Museum . ........................ 22

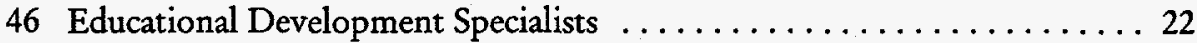

47 Energy Source Education Council $\ldots \ldots \ldots \ldots \ldots \ldots \ldots \ldots \ldots \ldots \ldots \ldots \ldots \ldots$

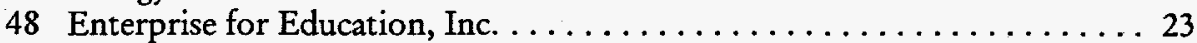

49 Environmental Hazards Management Institute (EHMI) . . . . . . . . 24

50 EV Media . . .............................. 24

51 Exxon Company, U.S.A. ....................... 25

52 Flexible Packaging Educational Association $\ldots \ldots \ldots \ldots \ldots \ldots \ldots 25$

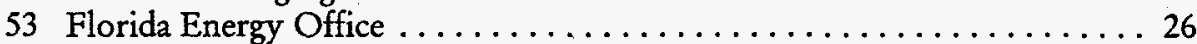

54 Florida Power \& Light Company ..................... 26

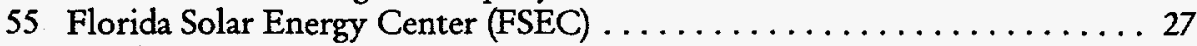

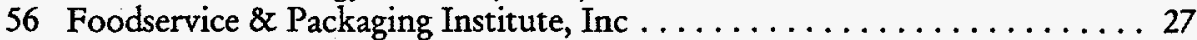

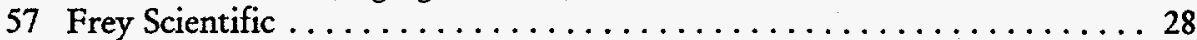

58 General Atomics Sciences Education Foundation $\ldots \ldots \ldots \ldots \ldots \ldots 28$

59 Geothermal Education Office $\ldots \ldots \ldots \ldots \ldots \ldots \ldots \ldots \ldots \ldots \ldots$

60 GPU Energy . ................................ 29

61 Hawaiian Electric Company, Inc. .................. 30

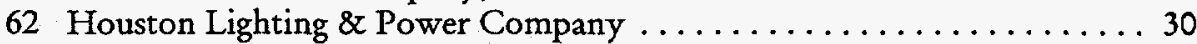

63 Illinois Department of Commerce and Community Affairs . . . . . . . 31

64 Independent Petroleum Association of America .............. 31

65 Indiana Department of Education .................... 32

66 The Institute for Chemical Education (ICE) $\ldots \ldots \ldots \ldots \ldots \ldots \ldots \ldots 32$

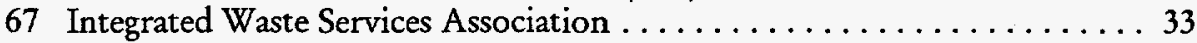

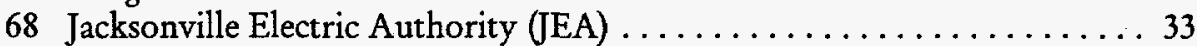

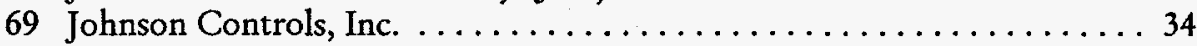

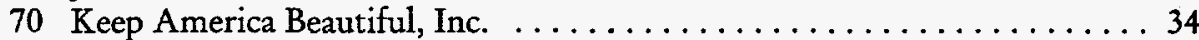

71 Kids For A Clean Environment (Kids F.A.C.E.) $\ldots \ldots \ldots \ldots \ldots \ldots \ldots$

72 Kissimmee Utility Authority (KUA) $\ldots \ldots \ldots \ldots \ldots \ldots \ldots \ldots \ldots \ldots \ldots \ldots \ldots$

73 The Learning Works . . . . . . . . . . . . . . . . . . . 36

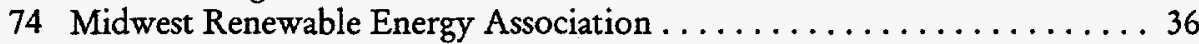

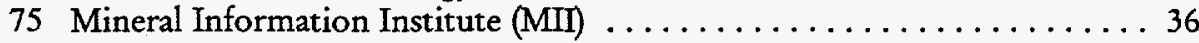

76 Minnesota Department of Public Service ................. 37

77 National Aeronautics and Space Administration (NASA) $\ldots \ldots \ldots \ldots 37$

78 National Arbor Day Foundation . . . . . . . . . . . . . . . . . 38

79 National Association of Conservation Districts (NACD) . . . . . . . 38

80 National Corn Growers Association $\ldots \ldots \ldots \ldots \ldots \ldots \ldots \ldots \ldots \ldots$

81 National Cotton Council of America . . . . . . . . . . . . . . . 39

82 National Energy Education Development Project (NEED) . . . . . . . 40

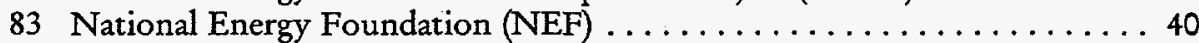

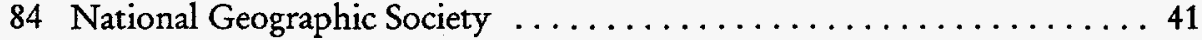

85 The National Hydropower Association $\ldots \ldots \ldots \ldots \ldots \ldots \ldots \ldots 41$

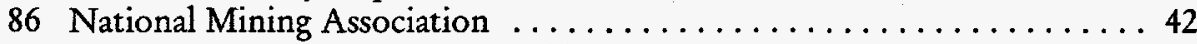

87 National Network of Energy and

Environmental Education Professionals ............. 42 
88 National Propane Gas Association . . . . . . . . . . . . . . . 43

89 National Rural Electric Cooperative Association . . . . . . . . . . . 43

90 National Science Foundation $\ldots \ldots \ldots \ldots \ldots \ldots \ldots \ldots \ldots \ldots \ldots$

91 National Science Resources Center (NSRC) . . . . . . . . . . . . . 44

92 National Science Teachers Association . . . . . . . . . . . . 45

93 National Wildlife Federation .................... 45

94 The Natural Gas Vehicle Coalition . . . . . . . . . . . . . . . . . . 46

95 Natural Gas Supply Association (NGSA) . . . . . . . . . . . . . . 46

96 New York State Geological Survey/State Museum . . . . . . . . . . . . 47

97 The NoodleHead Network ... . . . . . . . . . . . . . . . 47

98 Northeast Sustainable Energy Association (NESEA) . . . . . . . . . . 48

99 Northeast Utilities . . . . . . . . . . . . . . . . . . . . . . . . . . . 49

100 Northern Indiana Public Service Company . . . . . . . . . . . . . . 50

101 Northern States Power Company . . . . . . . . . . . . . . . . 50

102 Nuclear Energy Institute . . . . . . . . . . . . . . . . . . 50

103 Nuclear Information and Resource Service . . . . . . . . . . . . . 51

104 OG\&E Electric Services . . . . . . . . . . . . . . . . . . . 51

105 Ohio Oil \& Gas Association . . . . . . . . . . . . . . . . 52

106 Oklahoma Energy Resources Board . . . . . . . . . . . . . 52

107 Omaha Public Power District . . . . . . . . . . . . . . . 53

108 Pacific Gas \& Electric Company . . . . . . . . . . . . . . . 53

109 PP\&L, Inc. . . . . . . . . . . . . . . . . . . . . 54

110 Plastic Bag Association . . . . . . . . . . . . . . . . 54

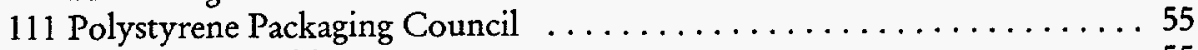

112 Procter $\&$ Gamble . . . . . . . . . . . . . . . . . . . . . . 55

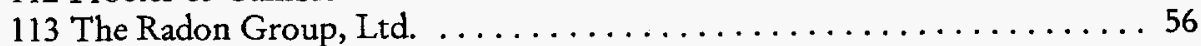

114 Railroad Commission of Texas . . . . . . . . . . . . . . . 56

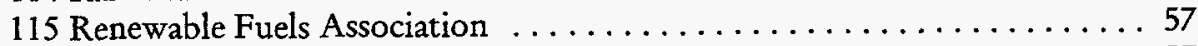

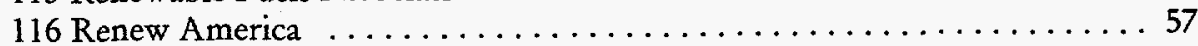

117 Safe Energy Communication Council . . . . . . . . . . . . . . 58

118 Science Screen Report . . . . . . . . . . . . . . . . . . 58

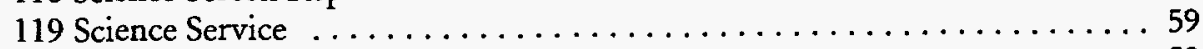

120 Shell Oil Company . . . . . . . . . . . . . . . . . . . . 59

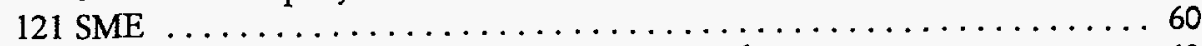

122 Society of Automotive Engineers International . . . . . . . . . . 60

123 Solar Energy Industries Association . . . . . . . . . . . . . 61

124 Solar Now . . . . . . . . . . . . . . . . . . . . . 61

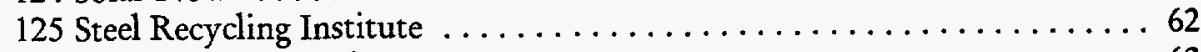

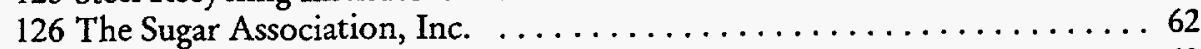

127 Troll School and Library . . . . . . . . . . . . . . . . 63

128 Union of Concerned Scientists . . . . . . . . . . . . . . . 63

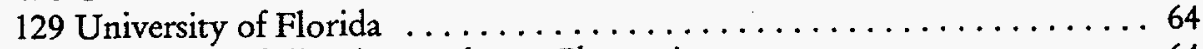

130 University of Illinois at Urbana-Champaign $\ldots \ldots \ldots \ldots \ldots \ldots \ldots \ldots$

131 U.S. Consumer Information Center . . . . . . . . . . . . . 65

U.S. Department of Agriculture 


\section{DISCLAIMER}

This report was prepared as an account of work sponsored by an agency of the United States Government. Neither the United States Government nor any agency thereof, nor any of their employees, makes any warranty, express or implied, or assumes any legal liability or responsibility for the accuracy, completeness, or usefulness of any information, apparatus, product, or process disclosed, or represents that its use would not infringe privately owned rights. Reference herein to any specific commercial product, process, or service by trade name, trademark, manufacturer, or otherwise does not necessarily constitute or imply its endorsement, recommendation, or favoring by the United States Government or any agency thereof. The views and opinions of authors expressed herein do not necessarily state or reflect those of the United States Government or any agency thereof. 


\section{DISCLAIMER}

Portions of this document may be illegible in electronic image products. Images are produced from the best available original document. 
U.S. Department of Education

134 ERIC Clearinghouse for Science, Mathematics,

and Environmental Education . . . . . . . . . . . . . 66

135 Office of Educational Research and Improvement (OERI) . . . . . . . 67

\section{U.S. Department of Energy}

136 Argonne National Laboratory . . . . . . . . . . . . . . . . . . . . 67

137 Bioenergy Feedstock Development Program .............. 68

138 Bonneville Power Administration . . . . . . . . . . . . . . . 68

139 Carbon Dioxide Information Analysis Center (CDIAC) . . . . . . . 69

140 Clean Cities Hotline . . . . . . . . . . . . . . . . . . . . . . 70

141 Energy Efficiency and Renewable Energy Clearinghouse (EREC) . . . . 70

142 Federal Energy Technology Center . . . . . . . . . . . . . . 71

143 Los Alamos National Laboratory $\ldots \ldots \ldots \ldots \ldots \ldots \ldots \ldots \ldots 71$

144 National Alternative Fuels Hotline $\ldots \ldots \ldots \ldots \ldots \ldots \ldots \ldots \ldots .72$

145 National Energy Information Center (NEIC) $\ldots \ldots \ldots \ldots \ldots \ldots \ldots 72$

146 National Low Level Waste Management Program ............. 73

147 National Renewable Energy Laboratory $\ldots \ldots \ldots \ldots \ldots \ldots \ldots \ldots$

148 Office of Civilian Radioactive Waste Management . . . . . . . . . 74

149 Office of Nuclear Energy, Science and Technology . . . . . . . . . 74

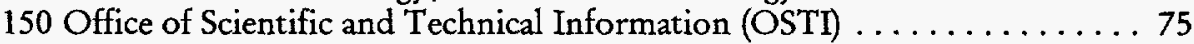

151 Pacific Northwest National Laboratory . . . . . . . . . . . . . . . . . 75

152 Western Area Power Administration $\ldots \ldots \ldots \ldots \ldots \ldots \ldots \ldots$

U.S. Department of the Interior

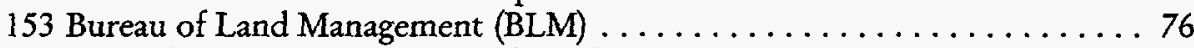

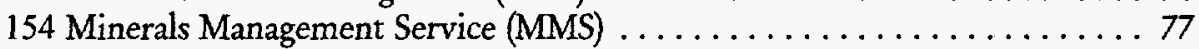

155 U.S. Environmental Protection Agency (EPA) . . . . . . . . . . . 78

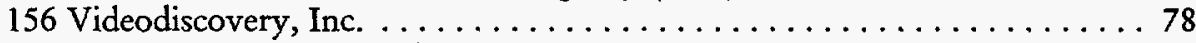

157 Water Environment Federation $\ldots \ldots \ldots \ldots \ldots \ldots \ldots \ldots \ldots \ldots$

158 Waverly Light and Power .......................... 79

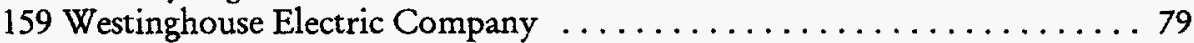

160 Wisconsin Public Service Corp. .................... 80

SUBJECT INDEX $\ldots \ldots \ldots \ldots \ldots \ldots \ldots \ldots \ldots \ldots \ldots \ldots \ldots$ 
Air \& Waste Management Association (A\&WMA)

One Gateway Center, Third Floor

Pittsburgh, PA 15222

(412) 232-3444

Fax: (412) 232-3450

E-Mail: info@awma.org

Web: http://www.awma.org

Founded in 1907, A\&WMA is a nonprofit, technical, and educational organization with over 14,000 members in 65 countries. This worldwide network represents many disciplines: physical and social sciences, health, engineering, law and management. It serves its members and the public by promoting environmental responsibility; provides technical and managerial leadership in the areas of air pollution control, environmental management, and waste processing and control.

Provides educational materials for teachers students in kindergarten through grade 12. Materials are designed to improve the environmental literacy of students and educators and introduce them to actions that they can take to reduce waste, conserve energy, and develop pollution prevention plans. Materials include fact sheets and information books on such topics as air pollution, pollution prevention, recycling, hazardous waste, landfills, and others. A\&WMA also produces Environmental Resource Guides (ERG's) on air quality and nonpoint source pollution prevention, which focuses on water quality and runoffs. The $E R G$ 's are supplementary curricula with a hands-on, interdisciplinary approach to environmental education. We encourage A\&WMA members and other interested parties to sponsor local teachertraining workshops. The workshops provide teachers an opportunity to participate in ERG activities and create an ongoing dialogue between environmental professionals and the educational community. Contact A\&WMA headquarters to find out about teacher-training opportunities in your area or to order public education materials.

The Alliance to Save Energy

120018 th Street, N.W., Suite 900

Washington, DC 20036

$1-(800) 376-6216$

(202) $857-0666$

Fax: (202) 331-9588

E-Mail: info@ase.org

Web: http://www.ase.org

A nonprofit coalition of business, government, environmental, and consumer leaders.

Consumers who send $\$ 3$ and a self-addressed \#10 envelope to: Power $\$$ marts, Alliance to Save Energy, P.O. Box 33939, Washington, DC 20033-0939, will receive an information-packed brochure entitled: Power \$marts Easy Tips to Save Money and the Planet. 
The Aluminum Association, Inc.

900 19th Street, N.W.

Washington, DC 20006-2168

(202) $862-5100$

Fax: (202) 862-5164

Web: http://www.aluminum.org

A trade association representing the U.S. aluminum industry. Serves as principal source of information on aluminum and the industry.

Provides educational materials on recycling for use in kindergarten through grade 12. Available free of charge is a brochure entitled Aluminum Recycles. Free catalogs are also available.

American Association for Vocational Instructional Materials

220 Smithonia Road

Winterville, GA 30683

$1-(800) 228-4689$

(706) $742-5355$

Fax: (706) $742-7005$

A nonprofit developer, publisher, and distributor of materials for vocational education.

Provides vocational instructional materials on electricity and electrical energy. Included are publications, computer software, and videos for reasonable fees. A free catalog is also available upon request. Publications available include Understanding Electricity; Electrical Wiring; How Electric Motors Start and Run; Fuels and Lubricants; Electric Motors; and Electrical Controls.

American Chemical Society

1155 16th Street, N.W.

Washington, DC 20036

(202) $872-4590$

Fax: (202) 833-7732

E-Mail: education@acs.org

Web: http://www.chemcenter.org

The world's largest scientific society, with a membership of nearly 150,000 chemists and chemical engineers.

Publishes educational materials for use in grades 4 through 12 . WonderScience is an exciting monthly hands-on science activities magazine for elementary school students (back issues are available); ChemMatters, an award-winning magazine for high school students, relates chemistry to everyday life (published quarterly, back issues are available); and Chem Com, also for high school 
students, a chemistry textbook that combines an emphasis on the role of chemistry in everyone's life with basic chemical knowledge. All three products deal with such energy-related topics as electricity, recycling, nuclear energy, and the environment. A free Teaching Resources Catalog is available upon request.

\section{American Coal Foundation}

113017 th Street, N.W., Suite 220

Washington, DC 20036-4604

(202) 466-8630

Fax: (202) 466-8632

E-Mail:mhornig@epochworks.com

Web: http://www.ket.org/Trips/Coal/ACF.html

http://www.nma.org/edsources.html

A nonprofit educational organization supported by a coalition of coal producers, electric utilities, railroads, equipment suppliers, sellers, and the labor union.

Provides materials and a video on coal production, distribution, usage, research, and the environment. Some of the materials are available in teacher packages which may be reproduced free of charge. Also available free of charge is a coal kit containing samples of peat, lignite, bituminous coal, and anthracite, and a brief description of the formation and different types of coal.

American Council for an Energy-Efficient Economy (ACEEE)

1001 Connecticut Avenue, N.W., \#801

Washington, DC 20036

(202) $429-8873$

Fax: (202) 429-2248

E-Mail: aceee@ix.netcom.com

Web: http://aceee.org

An independent, nonprofit organization dedicated to advancing energy efficiency as a means of promoting both environmental protection and economic prosperity.

Publishes a variety of books, reports, consumer guides, and fact sheets. Material covers energy use, efficiency, and related environmental issues in buildings, industry, and transportation. ACEEE's books and reports are written primarily for adults and concern energy-efficient technologies and policies. In addition, the Consumer Guide to Home Energy Savings is a popular illustrated handbook for consumers, and is a suitable teaching resource for grades 8 through 12 . These materials are available for a fee and are described in a free catalog. ACEEE also provides fact sheets, free of charge, on energy efficient appliances, energy and the environment, and guidelines for home energy conservation. 


\section{American Forest Foundation}

Project Learning Tree

1111 19th Street, N.W., Suite 780

Washington, DC 20036

(202) 463-2462

Fax: (202) 463-2461

E-Mail: yolanda-jacobs@plt.org

Web: http://www.plt.org

Develops, funds, and administers programs that encourage the long-term stewardship of our natural resources. The Foundation's core programs are Project Learning Tree (PLT) and American Tree Farm System.

PLT is co-sponsored by the American Forest Foundation and the Council for Environmental Education. PLT's newly revised curriculum guide, Project Learning Tree: Environmental Education Pre-kindergarten through Grade 8 Activity Guide, focuses on the total environment: land, air, and water. It is local, national, and global in scope. The new curriculum underscores PLT's primary goal - to help children learn how to think about complex environmental issues, not what to think about the environment. The curriculum remains easily adaptable to many settings from the classroom to youth organizations, museums, nature centers, and Scout troops. Nearly 100 activities are offered in a storyline technique covering the themes of diversity, interrelationships, systems, structure and scale, and patterns of change. Central to the new curriculum is an emphasis on constructivist learning theory, whole language teaching strategies, and correlations to national education standards. Background information, authentic assessment opportunities, an extensive bibliography, and a cross reference index are also included. A new curriculum made up of individual thematic modules, for use in grades 9 through 12, is also available. PLT curricular materials are available through local workshops. Contact PLT for the name of the program coordinator in your State.

\section{American Geological Institute (AGI)}

4220 King Street

Alexandria, VA 22302-1502

(703) $379-2480$

Fax: (703) 379-7563

E-Mail: ehr@agiweb.org

Web: http://www.agiweb.org/

Established in 1948, the American Geological Institute (AGI) is a nonprofit federation of 30 member organizations representing more than 80,000 geologists, geophysicists, and other earth scientists.

Distributes information on Earth science education through several mechanisms, including publications (textbooks, monographs, a monthly magazine entitled Geotimes, brochures), public inquiries, outreach programs (workshops and presentations), compact discs and a laser disc. Careers in the Geosciences (1-10 copies free) is one of the publications available. Compiled and distributed since 1990, the Earth Science Education Resource Directory provides 
information on Earth science educational materials that are available from nonprofit organizations. The list is updated annually and is available in hard copy and through electronic mail at the address above. AGI's goals are to advance and promote the geosciences through improved public information, expanded professional services to the geoscience community, and increase earth science educational programs at the college and precollege levels. For additional information, write to AGI Publications Center, P.O. Box 205, Annapolis Junction, MD 20701, (301) 953-1744 or fax at (301) 953-2838.

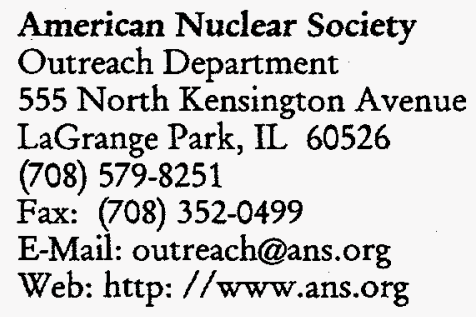

A nonprofit scientific and educational organization of professionals in the field of nuclear science and technology.

Offers free publications (single copies) on nuclear energy and uses of the atom. Available materials include Nuclear Energy Facts QEA, Nuclear Technology Creates Careers, Personal Radiation Dose Chart, and a simulated nuclear fuel pellet. Science and social studies curricula materials for use in kindergarten through grade 12 may be borrowed or purchased. A free catalog is available upon request by mail or electronic mail at outreach@ans.org. Teachers may sign up for the free newsletter ReActions, which contains articles on uses of the atom in everyday life and--in each issue-an "activity card" with a project for classroom use. Short workshops and sessions are held throughout the year at exhibits, conferences, in-service training, and by invitation.

\section{American Petroleum Institute}

Public Relations Department

1220 L Street, N.W.

Washington, DC 20005

(202) $682-8118$

Web: http://www.api.org

\section{A national trade association that encompasses all branches of the petroleum industry.}

Supplies educational materials on the petroleum industry to teachers at no charge. Available materials include a video for middle school students that illustrates with pop music and dance the often invisible role that petroleum products play in our lives. Entitled "Fuel-Less, You Can't Be Cool Without 
Fuel," is also being distributred by the National Science Teachers Association. One per classroom. The Ecosystem of Oil explains the role of petroleum throughout history, emphasizing the petroleum industry's commitment in safeguarding environmental and wildlife resources. Classroom sets of up to 35 are available. Running on $\mathrm{Oil}$ is a booklet which includes an eight-page feature article on oil; a large colorful poster for classroom display; and classroom activities demonstrating the scientific properties and role of oil in modern life. One per classroom. Available in classroom sets of up to 35 is an oil barrel-shaped card entitled Facts About Oil, which contains oil industry facts including the number of people who work in the industry, used motor oil collection, gasoline taxes paid, and petroleum products and petrochemicals made from a barrel of crude oil. Also available is a brochure entitled Facts About Natural Gas and a publication entitled All About Petroleum.

\section{American Plastics Council (APC)}

1801 K Street, N.W., Suite 701L

Washington, DC 20006

1-(800) 2-HELP-90

(202) $974-5379$

Fax: (202) 296-7119

Web: http: //www.plasticsresource.com

The American Plastics Council (APC) is the major national trade association representing the U.S. plastics industry on resource conservation issues. APC works on behalf of the overall plastics industry to enhance the integrity of plastics, focusing on resource management-related environmental issues. Its mission is to ensure that plastics are a preferred material in a more environmentally conscious world.

APC, in conjunction with the National Middle Level Science Teachers Association, has created a unique hands-on kit, designed to help middle level science classes explore the world of plastics. Included in "Hands On Plastics: A Scientific Investigation Kit" are written background information, recycled plastic resin samples, and learning cycle lesson plans to teach your class about chemical structures, identification codes, and recycling. The kit is available for a nominal fee. Additional educational materials include Plastics in Perspective, a booklet that answers the most frequently asked questions about plastics in the environment, and an 11-minute video entitled "The Busy, Busy Planet." The video addresses issues such as source reduction, energy efficiency and recycling, and illustrates the many ways plastics benefit our lives and our environment. Single copies of each of these materials are free to educators, and can be obtained by calling the information line or through the Web site listed above. 
American Public Power Association

2301 M Street, N.W., Suite 300

Washington, DC 20037

(202) 467-2900

Web: http://www.appanet.org

A service organization for not-for-profit community-owned electric utilities.

Provides various pamphlets, including The Benefits of Public Power; Profile of Power; Careers in Public Power; and All About Electricity and 10 Ways Kids Can Save It. Offers a Teaching Unit on Electromagnetic Waves, which was developed by the Los Angeles Department of Water and Power for junior high and senior high school students. Also available are two videos, "Simple Things You Can Do to Save Energy" and "Simple Things You Can Do to Save Energy in Your School." The videos were prepared by the Burlington (Vermont) Electric Department through the American Public Power Association's DEED (Demonstration of Energy Efficient Developments) program. Publications and videos are offered for a nominal fee. A free catalog is available.

American Solar Energy Society

2400 Central Avenue, Suite G-1

Boulder, CO 80301

(303) 443-3130

Fax: (303) 443-3212

E-Mail: ases@ases.org

Web: http://www.ases.org/solar

A national membership association dedicated to advancing the use of solar energy.

Offers sample copies of its magazine Solar Today and publication catalog. Has one science project book, Elementary and Secondary Science Projects in Renewable Energy and Energy Efficiency, available for a fee.

\section{American Water Works Association \\ 6666 West Quincy Avenue \\ Denver, CO 80235 \\ (303) 794-7711 \\ (303) 347-6140 (Youth Education) \\ Fax: (303) 794-7310}

E-Mail: bmuslim@awwa.org

Web: http://www.awwa.org

An international, nonprofit, scientific, and educational organization of professionals associated with the public drinking water industry, including utilities, manufacturers, consultants, researchers, and educators. 
Provides educational materials designed to teach young people about water treatment, distribution, and conservation. Materials include activity books, teacher's guides, comic style books, computer software, videos, bookcovers, and novelty items. A free Youth Education Sample Packet and other educational materials may be ordered directly from AWWA headquarters in Denver. The packet includes an AWWA Youth Education Catalog. To place orders, telephone the AWWA Bookstore at 1-800-926-7337 or access it on the Web site above.

American Wind Energy Association

122 C Street, N.W., Fourth Floor

Washington, DC 20001

(202) $383-2500$

Fax: (202) 383-2505

E-Mail: windmail@mcimail.com

Web: http://www.igc.apc.org/awea/

The American Wind Energy Association (AWEA) represents wind energy as a technology that is economically and technically viable today.

Offers an Educator's Packet on wind energy including: the current Wind Energy Status Report, which outlines the domestic and international growth of the wind industry; the Basic Facts About Wind Energy, which discusses the scale of wind projects as well as economic development; and a Wind Energy Information Guide, a compilation of further sources to contact for information about wind energy. Elementary (grades 4 through 7) and secondary (grades 8 through 12) fact sheets and a simple experiment are also provided for use in the classroom. This packet is available free upon request. Other educational materials like videos and posters are available for a fee through the AWEA publications catalog.

Apple Computer, Inc.

1 Infinite Loop

Cupertino, CA 95014

1-(800) 800-2775

E-Mail: ewhite@apple.com

Web: http://www.apple.com/education/ali

Develops, manufactures, and markets personal computers for use in education, business, science, engineering, and government.

Apple Computer, Inc. ignited the personal computer revolution in the 1970s with the Apple II, and reinvented the personal computer in the 1980s with the Macintosh. Apple is now recommitted to its original mission-to-bring the best personal computing products and support to students, educators, designers, scientists, engineers, business persons and consumers in 140 countries around the world. 
In 1998, Apple introduced several new products and software solutions specifically for kindergarten through grade 12 schools. The first was the new G3 All-In-One Macintosh that brings the latest technology to schools at an affordable price with sufficient power for multimedia design and authoring tools. In the summer of 1998 Apple will ship the new iMac for schools that focus on connecting to the Internet and incorporates the latest in design technology at the lowest possible cost. Apple has also introduced several new software bundles as part of the Apple Education Series. New bundles include Middle School Connections, Advanced Reference Tools, Elementary Reference and Creativity Tools, and Internet Connections, all of which support reference and learning on energy and environmental issues.

The Apple Learning Interchange is an Apple-sponsored Web site where teachers and students can find and share information on a wide variety of curriculum areas. ALI is free to all teachers and students at http://www.apple.com/education/ali.

\section{Arizona Department of Commerce}

Energy Office

3800 N. Central, Suite 1200

Phoenix, AZ 85012

(602) $280-1402$

Fax: (602) 280-1445

E-Mail: jima@ep.state.az.us

Web: http://www.commerce.state.az.us/

\section{A DOE-funded program that emphasizes an energy efficiency curriculum} for students in kindergarten through grade 12.

Provides the following materials and services for primary and secondary schools: Bright Ideas (single-topic publications covering energy and the environment, recycling, solar cooking, and photovoltaics); Energy Patrol: Turn Off Those Lights and Marketing Energy Patrol.

The Aseptic Packaging Council

P.O. Box 3794

Washington, DC 20007

$1-(800) 277-8088$

Web: http://www.aseptic.org

A trade association representing the U.S. manufacturers of drink boxes. The APC's primary mission is to inform the American public about the product benefits and environmental attributes of aseptic packaging.

Offers free educational materials on recycling issues for teachers and students. Waste Wise: Concepts in Waste Management, a teacher's discussion guide, can be adapted for particular classes from kindergarten through grade 12 . We also have available a poster, What's New In Recycling, which complements the teaching guide. A general information brochure may also be ordered. 
The Bakken Library and Museum

3537 Zenith Avenue South

Minneapolis, MN 55416

(612) $927-6508$

Fax: (612) $927-7265$

Web: http://www.bakkenmuseum.org

A nonprofit educational organization with library and museum collections documenting the history of electromagnetism and its uses in the life sciences.

The Bakken has developed a book and kit to teach students how scientists of the 18th century succeeded in developing the basis for all we know about electrostatics, equipped only with their powers of observation and simple apparatus. The kit has easy-to-assemble apparatus commonly found in an 18thcentury electrical laboratory, a 22-minute video tape, and a 100-page curriculum manual. The manual has instructions for demonstrations and experiments, methods for adapting the experiments for students from the elementary grades through high school, and gives the historical context in which key discoveries were made. Designed and tested by The Bakken Library and Museum, this kit offers an excellent introduction to teaching basic electricity and the history of science.

By using this inquiry-based approach, students gain deeper insight into the principles of electrostatics. The development of the kit was co-funded by the National Science Foundation. This kit is available for sale from The Bakken. The video and curriculum manual are available separately. Write or fax to obtain The Bakken's current list of other educational resources for sale or to receive our free newsletters.

\section{Baltimore Gas and Electric Company (BGE)}

Educational Services

P.O. Box 1475

Baltimore, MD 21203-1475

(410) $234-7484$

Fax: (410) 234-7471

An investor-owned utility serving Baltimore City and all, or parts of, nine central Maryland counties.

Provides educational services free of charge to schools in BGE's service area. Services include classroom programs, career programs, resources, certified workshops for educators; and videos, power plant tours, and classroom literature for students in kindergarten through grade 12. A free Educational Resources catalog is available upon request. 


\section{BP America}

Corporate Communications

200 Public Square (10-L)

Cleveland, OH 44114-2375

(216) 586-3794

Fax: (216) 586-6957

E-Mail: DAVISVD@bp.com

The wholly owned U.S. subsidiary of one of the world's largest international petroleum and petrochemical groups.

Science Across America makes it possible for students to exchange their scientific work with others throughout the United States and around the world. The program includes eight teaching modules designed for students in grades 7 through 12. The units deal with those issues which are of international environmental interest (e.g., energy and drinking water quality) and are common to science courses internationally. There is a fee, which includes lifetime registration on a worldwide database of participating schools. For more information, write to the address above. BP Statistical Review of World Energy, a booklet containing information on world energy supplies and demand, includes data on oil, gas, coal, nuclear, and hydro in terms of reserves, production, and consumption for a 10-year period before the current year. Also available is Facts, BP's annual report on health, safety and the environment. These publications are free to teachers. Contact above address. Also available is the $B P$ Educational Resources Catalogue, which offers a full range of school resource materials. Some of the items in the catalogue are available for a fee.

\section{Bronx Zoo/Wildlife Conservation Park}

Education Department

2300 Southern Boulevard

Bronx, NY 10460

1-(800) $937-5131$

Fax: (718) 733-4460

Web: http://www.wcs.org

The purpose of the Wildlife Conservation Society, since its founding in 1895 as the New York Zoological Society, has been to save wildlife and inspire people to care about our natural heritage. The Society continues to pioneer environmental education programs throughout the U.S. and abroad. It is the world's leading international conservation program devoted to saving endangered species and ecosystems.

Offers Voyage From the Sun, a 20-lesson classroom science module for grades 4 through 9. Developed with funding from the U.S. Department of Energy, Voyage is designed to introduce students to the major way in which energy is important to wildlife and natural habitats. It encourages students to explore the story of Earth's energy-its solar origins, how it is incorporated into living systems through photosynthesis, and how it flows from plants to animals. 
During Voyage training workshops, teachers learn strategies for making the study of energy fun and exciting. Teachers receive first-hand training in how to guide their students as the 4-foot-high Energy Pyramid becomes a classroom exhibit on energy. Through activities such as Photosynthesis Scramble and Conserving Energy: Tundra Math, teachers build the confidence to lead students on a voyage of discovery as they explore how energy is central to biology and how it links the natural and physical sciences. For more information, call the Manager of National Programs at the number above. 23

Bullfrog Films

P.O. Box 149

Oley, PA 19547

$1-(800)$ 543-3764

Fax: (610) 370-1978

E-Mail: bullfrog@igc.org

Web: http://www.bullfrogfilms.com

An educational film distributor that offers the largest collection of energy films and videos in the country.

Provides educational films and videos on energy and energy-related issues. Titles include Bill Loosely's Heat Pump; Decision: Energy for the Future; The Energy Bank; Energy Efficiency; Energy, Technology and Society; Harness the Wind; Living Under the Cloud: Chernobyl Today; Race for the Future; Solar Promise; Go; An Energy-Efficient Doghouse; Solar Energy Doghouse; City Lights; Rethink-Pollution Prevention Pays; Recycling With Worms; Planet Neighborbood; Water and the Human Spirit; It's Eco-Logic and Wake Up Freddy, in the tradition of Bullfrog's classic Toast. Programs are available for purchase or rental. Special packages, with discounted prices, can be created to serve most schools' needs. A free catalog is available upon request.

\section{California Energy Commission}

1516 9th Street, MS-29

Sacramento, CA 95814

(916) $654-4989$

Fax: (916) 654-4420

E-Mail: cecetec@energy.ca.gov

Web: http://www.energy.ca.gov/education (Energy Quest)

http://www.energy.ca.gov (Access Energy)

The California Energy Commission is the State's principal energy planning organization, promoting a balanced and competitive energy system through its diverse programs.

Provides the following printed energy and environmental education material for kindergarten through grade 12 (more resources on-line): Compendium for 
Human Communities (curriculum evaluation); Universal House; Energy Shelter \& the California Indian; Conserve and Renew; Energy Tech-Knowledgy; Energy Patrol. Energy Quest, an on-line resource for students, teachers and parents is dedicated solely to energy education and features information on renewable energy, conservation, safety, energy-related math and science experiments; Ask Us (for energy questions); word games and links to other resources. Devoured by the Dark is a Goosebumps-like energy story exploring a travel-through-time adventure for children. Access Energy is geared towards the adult and older student (grades 10 through 12) for energy information. 25

\section{California Foundation for Agriculture in the Classroom}

2300 River Plaza Drive

Sacramento, CA 95833

(916) $561-5625$

Fax: (916) 561-5697

E-Mail: cfaitc@cfbf.org

Web: http://www.cfaitc.org

A nonprofit educational foundation that provides educational resources and training for teachers to use agriculture as an integration theme throughout kindergarten through grade 12 curricula.

Teachers may request free or low-cost items including lesson plans, comprehensive classroom units, videos, a resource guide, and the Cream of the Crop newsletter. Most programs are specific to California but a limited number of resources may be available for use in other States. Among lesson plans available, some have Spanish language worksheets. All lesson plans are correlated with California curriculum frameworks and undergo extensive field testing and teacher and technical review.

The Foundation encourages classroom integration of agriculture to increase understanding of its vital role in our lives. Agriculture provides a theme which encourages hands-on activities to reinforce concepts in science/environment, mathematics, English/language arts, history/social science, health/nutrition, physical education and the visual and performing arts. Contact with the Foundation is a good starting point for teaching other agriculture-related groups that produce educational resources. Educational materials developed by industries and organizations related to agriculture are reviewed by the Foundation and listed in an annually updated Teacher Resource Guide. 
The Center for Energy and Economic Development (CEED)

1800 Diagonal Road, Suite 370

Alexandria, VA 22314

(703) 684-6292

Fax: (703) 684-6297

E-Mail: info@ceednet.org

Web: http://www.ceednet.org

A nonprofit organization dedicated to preserving coal's role as an economical, efficient, and environmentally compatible source of electricity.

Provides information related to low-cost, reliable, environmentally compatible electricity. Coal, America's most abundant domestic energy resource, is responsible for approximately 60 percent of the electricity generated in America. Coal-fired electricity generation brings benefit to Americans from all walks of life. CEED provides resource materials related to coal-fired electricity generation. Most CEED materials are available through the Web site listed above.

Center for Renewable Energy and Sustainable Technology (CREST) 120018 th Street, N.W., 9th Floor

Washington, DC 20036

(202) $530-2202$

Fax: (202) 887-0497

E-Mail: info@crest.org

Web: http://www.crest.org/

The Center for Renewable Energy and Sustainable Technology (CREST), a nonprofit organization dedicated to promoting renewable energy and sustainable development using advanced communications and computer technology.

CREST operates an on-line clearinghouse of renewable energy and energy efficiency information called SOLSTICE, which provides free electronic access to documents, images, directories, and other databases around the world. SOLSTICE can be accessed via File Transfer Protocol (ftp to "solstice.crest.org") and the World Wide Web ("http://solstice.crest.org/"). CREST has published multimedia educational CD-ROMs about renewable energy, efficiency, and global climate change, including the Sun's Joules multimedia encyclopedia on renewable energy; School Energy Doctor Auditing software; the Greening of the White House CD-ROM; SpanishEnglish CD-ROM on Renewable Energy in Latin America; and a renewable energy demonstration module. In addition, CREST teamed up with WETA, a Washington DC PBS station, to create the Green Home CD-ROM as a companion to the series "Planet Neighborhood." All titles are available in Mac or Windows versions, and can be ordered through the Web site or by calling 1-800-346-0104 or (541) 484-9353. 
Channing L. Bete Publishing Co., Inc.

200 State Road

South Deerfield, MA 01373-0200

$1-(800)$ 628-7733

Fax: (413) 665-2671

E-Mail: akowaleck@channing-bete.com

Web: http://www.channing-bete.com

A publishing firm specializing in Scriptographic Booklets. Most utilities provide them to schools in their service territories free of charge; however, the booklets are available from the publisher for a fee.

Offers My Book series, designed for students in kindergarten and grade 1; Coloring and Activities Books for students in grades 1 through 3; and Information and Activities Books for students in grades 4 through 6. "Experiment Kits" on Conservation, Energy, and Electricity, all for students in grades 4 through 6, are available. Each kit contains 35 student workbooks and one instructor's guide. Water, Electric and Energy Conservation stickers and growth charts are also available. Offers a 6th grade curriculum entitled "Water Week," which includes hydropower information. Contact your local utility for availability or call the above number. Provides educational services fulfillment for utilities.

Charles Edison Fund

101 South Harrison Street

East Orange, NJ 07018

(201) 675-9000

Fax: (201) 675-3345

A charitable foundation providing science teachers with simple, basic, proven fun experimental booklets containing 73 experiments.

Provides "The Best of Edison Science Teaching Kits," which are available to teachers. Each kit contains nine how-to booklets based on experiments of Thomas Edison and other scientists. These are suitable for grades 4 through 8. Titles include: Energy for the Future; Useful Science Projects; Environmental Experiments; Selected Experiments and Projects; Nuclear Experiments; Energy Conservation; Alternative Energy Sources; Static Electricity -. It's a Snap; and Lewis Howard Latimer Experiments. There is a small fee for handling charges. Write for coupon to receive this kit. 
The Chlorine Chemistry Council (CCC)

1300 Wilson Boulevard

Arlington, VA 22209

(202) $452-9493$

Fax: (202) 296-7285

E-Mail: info@C3.org

Web: http://C3.org

The Chlorine Chemistry Council is part of the Chemical Manufacturers Association established to provide information to the public regarding chlorine and to promote the practice and understanding of responsible use for chlorine chemistry.

Making the connection between the periodic table and real life can be challenging, particularly for middle school teachers. CCC offers hands-on materials designed to introduce basic chemistry and the periodic table. By taking a look at one element - chlorine - teachers can help students understand the link between chemical "building blocks" and daily life. The video, hand-outs, experiments, and lesson guides in the Building Block Chemistry Program were developed by teachers for teachers to help students explore their world. For FREE classroom materials and video, write to the address above.

City Public Service (CPS)

Consumer Services Section

P.O. Box 1771

San Antonio, TX 78296-1771

(210) $978-2833$

Fax: (210) 978-4327

E-Mail merandle@cps-satx.com

Web: http://citypublicservice.com

A municipally owned natural gas and electric utility serving substantially all of Bexar County and small portions of seven adjacent counties.

Provides safety and energy educational services free of charge to schools in the CPS service area. Services include classroom presentations, a video tape library, curriculum supplements, and power plant tours. A free CPS School Safety \& Energy Education Program Catalog is available upon request. 
City Utilities of Springfield

301 E. Central

P.O. Box 551

Springfield, MO 65801-0551

(417) 831-8311

Fax: (417) 831-8454

E-Mail: edecamp@mail.orion.org

A municipal utility serving the metropolitan area of Springfield with electricity, natural gas, and water.

Provides educational services free to instructors in areas served by City Utilities. Offers tours to power plants and water treatment plants, classroom presentations, speakers' bureau, and purchased curriculum materials for students in kindergarten through grade 12. City Utilities also has special units, "The Planet Water" and "Are You Being Safety Conscious Around Electricity." Single copies are available to teachers outside City Utilities' service area.

\section{Cobblestone Publishing}

30 Grove Street

Peterborough, NH 03458

1 -(800) $821-0115$

Fax: (603) 924-7380

E-Mail: custsvc@cobblestone.mv.com

Web: http://www.cobblestonepub.com

A publishing firm specializing in magazines for children and teaching resources.

Publishes educational materials for students in grades 5 through 8. Energyrelated titles are: Energy: Powering Our Nation; Recycling; Earth: A Global Spaceship; Planet Earth: Home Sweet Home; and a theme pack with activities, ENVIRONMENT. Materials may be purchased from the publisher. Free catalogs are available upon request.

\section{Colorado School of Mines}

Teacher Enhancement Program

Office of Special Programs and Continuing Education

Golden, CO 80401

1-(800) $446-9488 \times 3303$

Fax: (303) 273-3314

Web: http://www.mines.edu/Outreach/Cont_Ed/teacher.shtml

A State college of science and engineering teacher enhancement program offering coursework and resources for primary school and secondary school educators in science, energy, math, technology, and the environment. 
Three times a year, provides a free catalog of course listings specifically for teachers. Courses carry graduate-level recertification credit and offer content-based instruction; practical hands-on experience; and, in some cases, extensive field trips. Offers for a nominal fee What's Under Your Feet, an earth science activity book for students in kindergarten through grade 6; Sharing Science with Children, a survival guide for visiting scientists and engineers in the classroom; and Sharing Science: Linking Students with Scientists and Engineers, a survival guide for teachers.

The Consumer Aerosol Products Council

1201 Connecticut Avenue, N.W., Suite 300

Washington, DC 20036

(202) 833-9471

Web: http://www.nocfcs.org

Supported by companies that manufacture and market aerosol products, the Consumer Aerosol Products Council (CAPCO) was formed to provide information on aerosols and environmental issues for consumers, media, and educators at all levels.

Offers "Another Awesome Aerosol Adventure" educational unit for students in grades 4 through 8 . Included is an 11 -minute video produced by the makers of the children's television program "Beakman's World." Designed with humor in mind, the video, along with accompanying teacher and student guides and take-apart aerosol can, makes the complex issues of aerosol technology, ozone depletion, and environmental awareness memorable and fun for a middle school-age audience. "Another Awesome Aerosol Adventure" is available through Modern Sponsored Marketing Services. To order, call Modern's toll free number 1-800-243-6877 and ask for digest \#K-0190-A. 36

\section{Culver Company}

316 Merrimac Street

Newburyport, MA 01950

1-(800) 4-CULVER

Fax: (978) 463-1715

E-Mail: order@culverco.com

Web: http://www.culverco.com

A developer and publisher of educational materials about energy and related topics.

Produces booklets, videos, posters, and program enhancement items for children and adults. Teacher discussion guides are also available. Utilities purchase and distribute these materials in their service areas; other organizations may purchase them directly. 


\section{Dayton Power \& Light Company}

School Programs

1065 Woodman Drive

Dayton, OH 45432

(937) $259-7251$

Fax: (937) 259-7813

An investor-owned electric, steam and natural gas utility that serves 464,000 customers in 24 counties of a 6,000-square-mile area in west central Ohio.

Provides free educational programs and resources for students in kindergarten through grade 12 to schools within the utility's service area. Programs include a customized computer software program on energy conservation; an electric and natural gas safety program; science fair kits for teachers and a recognition event for top science fair projects; workshops to provide educators with energy-related information and resources; power plant slide shows; and classroom presentations. Materials provided include booklets, videos, posters, student handbooks, and teacher's guides with classroom activities.

Denver Earth Science Project

Office of Special Programs \& Continuing Education

Colorado School of Mines

Golden, CO 80401

$1-(800)$ 446-9488 x3038

Fax: (303) 273-3314

E-Mail: jproud@mines.edu

Web: http://www.mines.edu/Outreach/Cont_Ed/desp.shtml

A teacher enhancement program, in partnership with corporations, Federal agencies, school districts, and professional organizations, which provides innovative earth science curriculum materials for use in kindergarten through grade 12 and teacher training.

Provides, for a fee, a series of educational workshops that address a range of earth science topics developed by trained curriculum development teams. The team members are experienced earth science teachers and practicing scientists. The hands-on student activities included in each module incorporate real data and follow a problem-solving approach. Each module integrates mathematics, geography, economics, and social and environmental issues with basic earth science concepts. The modules are:

- "Oil and Gas Exploration" (grades 7-12)

- "Ground Water Studies" (grades 7-9)

- "Paleontology and Dinosaurs" (grades 7-9)

- "Energy - A Closer Look at Oil and Gas" (grades 4-6)

Each module contains a teacher resource kit which includes a teacher/student notebook, maps, audio-visual materials, posters, oil samples, groundwater models, etc. Call to find out the location of the nearest training site. 


\section{Disney Educational Productions}

105 Terry Drive, Suite 120

Newtown, PA 18940

$1-(800) 295-5010$

Fax: (215) 579-8589

Disney Educational Productions develops and distributes entertaining and thought-provoking videos and interactive laser discs that excite children of all ages to learn about a variety of subjects.

Offers educational videos and videodiscs on energy, the environment, earth science, recycling, and water. Curriculum-oriented videos come with discussion guides and lesson plans. Titles include:

- Bill Nye the Science Guy shows, such as Pollution Solutions, Garbage and The Water Cycle

- Recycle Rex (starring Disney's hip animated recycling dinosaur)

- The Energy Savers (starring Donald Duck, Mickey Mouse and Goofy)

- Zort Sorts: A Story About Recycling

- The Great Search - Man's Need for Power and Energy

Interactive laser discs, such as Recycle Rex and Discover Quest: Explorations in Earth Science, encourage learning with a mix of videos, interviews, games, on-line glossaries, and comprehensive guidebooks. Programs are available for purchase or lease. Call the toll-free number to request a free catalog.

\section{E2: Environment \& Education}

P.O. Box 20515

Boulder, CO 80308-3515

(303) $442-3339$

Fax: (303) 442-6633

E-Mail: e2ee@enviroaction.org

Web: http://www.enviroaction.org

A nonprofit organization dedicated to helping young people develop an awareness of environmental challenges, and the understanding and skill to take informed and effective action.

Developed Environmental ACTION (Analyze, Consider Options, Take Action, In Qur Neighborhoods). This is a relevant, supportive and clearly structured interdisciplinary environmental education curriculum for grades 6 through 12. The program offers six separate modules: Energy Conservation, Water Conservation, Waste Reduction, Chemicals: Choosing Wisely, Food Choices, and Habitats \& Biodiversity. Each module provides instruction on how to investigate environmental issues while creating opportunities to practice action skills. The hand-on activities move students from awareness to choice into action. Students conduct an audit of current resource consumption and research alternative practices, services, and technologies. They conclude with a plan for change based on a cost benefit analysis. By having students use the 
school community as their laboratory, the school becomes a model of sustainable practices. E2 has also developed a General Resources Guide for educators. For a fee, E2 will provide teacher training workshops.

\section{Earth Foundation}

5151 Mitchelldale, Suite B-11

Houston, TX 77092

(713) $686-1205$

Fax: (713) 686-6561

E-Mail: EarthFound@aol.com

Web: http://www.earthfound.com

\section{An organization dedicated to environmental education and conservation.}

Each year thousands of schools participate in the Earth Foundation's Rescue the Rainforest Project. Thus far, the network of 10,000 active environmental teachers and students is responsible for adopting over 150,000 acres of rainforest. A "Rainforest Project Kit" is available to educators. The kit, which includes curriculum, videos, instructions, and a ready-made fundraising project, contains everything a school will need to supplement an ecology unit with a teaching method called "Solution-Based Teaching." Upon completion, participating schools receive a certificate recognizing them for the acres adopted and written updates about the area being preserved. Schools that adopt 10 or more acres receive a free follow-up video that shows students live footage of the area. Call 1-800-5MONKEY to receive your "Rescue the Rainforest Kit" and for more information about this project or the Coral Reef Rescue Campaign.

\section{East Ohio Gas}

Educational Affairs Department

P.O. Box 5759

Cleveland, $\mathrm{OH} 44101-0759$

(216) $736-6218$

Fax: (216) 736-5323

Web: http://www.cng.com/eog/fcover.htm

A natural gas utility serving over one million customers in a 23-county area throughout northeast and southeast Ohio.

Promotes energy awareness in the community and emphasizes the importance of natural gas. Provides educational resources, free of charge, to primary school and secondary school educators in the areas served by East Ohio Gas. A free Educational Resources $\&$ Awards Catalog offers a variety of programs and materials. Topics include natural gas vehicles, natural gas safety, science fair planning, and parental resources. 
Edison Electric Institute (EEI)

Order and Billing

701 Pennsylvania Avenue, N.W.

Washington, DC 20004-2696

$1-(800) 334-5453$

(202) $508-5000$

Fax: (301) 843-0159

Web: http://www.eei.org

An association of shareholder-owned electric utilities.

Suggests that you first contact your local electric utility. Many utilities have educational programs about energy and the environment for schools. EEI's publications catalog is free. Other publications are available for a fee.

\section{Edison Plaza Museum}

P.O. Box 2951

350 Pine Street

Beaumont, TX 77704

(409) $981-3089$

Fax: (409) $981-2106$

Established in 1982 by Gulf States Utilities Company as a nonprofit, educational institution to focus on the inventions of Thomas A. Edison and show how the electric industry has expanded on his patents to improve the quality of life.

Contains the largest collection of original Edison artifacts west of the Mississippi River. All eight major fields of Edison's achievement are represented. The museum is housed in the historic Travis Street Substation - the first building to distribute electric power in east Texas. Exhibits include past, present, and future energy technologies. A free guide book, brochure, and children's book are available upon request and can be mailed anywhere.

Educational Development Specialists

5505 E. Carson Street, Suite 250

Lakewood, CA 90713

(562) 420-6814

Fax: (562) 420-1485

Energy and environmental education program developers and distributors.

Offers the Think Earth education program nationwide to sponsors who give the program to schools. This award-winning program interrelates air, land, water, and energy topics into a comprehensive environmental education school pack. It contains units for students in kindergarten through grade 6, plus a fully animated video. A free catalog is available on the program. 
Energy Source Education Council

Program Distribution Office

5505 E. Carson Street, Suite 250

Lakewood, CA 90713

(562) $420-6814$

Fax: (562) 420-1485

A nonprofit organization involved in developing and distributing quality energy educational programs.

Has an Energy Source Education Program that is financially supported by member organizations (mostly utilities) from the private sector. Material is sold to the utility companies who then distribute it at no charge to classrooms in their service areas. Material to others is available for a fee. A free catalog is available.

Enterprise for Education, Inc.

1316 Third Street, Suite 103

Santa Monica, CA 90401

(310) 394-9864

Fax: (310) 394-3539

Offers booklets for primary school and secondary school science classes FREE from many electric utilities.

Supplies a variety of 8 and 16-page Energy and Environmental Skill Builder color booklets. Teachers can create short to comprehensive units based on the subject and grade level. The following are available:

- $\quad$ Environmental -- "Using Our Resources Wisely" (grades 2-4); "The Greenhouse Effect and Global Warming" (grades 6-12); and "Percentages Help an Environmental Engineer" (grades 6-8); "The Clean Air Challenge" ( 32 pages with video and science experiment kit, (grades 8-10)

- Conservation -- "Efficiency of Electric Appliances" (grades 6-10); "Climate and Comfort" (grades 6-12); and "Is Efficiency the Best Energy Source?" (grades 9-12)

- Nuclear Energy -- "Nuclear Reactor" (grades 8-12); "The Atom and Radiation" (grades 6-12); and "Nuclear Fuel Cycle" (grades 8-12)

- Fossil Fuel -- "Coal: The Once and Future King?" (grades 6-9); "Natural Gas" (grades 6-12); "Geology of Oil" (grades 6-12); and "Refining Oil" (grades 8-12)

- $\quad$ Electricity -- "Mouse House Surprise," a 32-page Teacher BIG book and student little book (grades K-2); "Sam and Jody Save the Circus" (safety) (grades 2 and 3); "Paths for Electricity" (safety) (grades 3-5); 
"Energy Transformations" (grades 4-9); "Generating Electricity" (grades 5-9); "Sources of Electricity" (grades 5-9); "Demand for Electricity" (grades 6-9); "Working With Energy Graphs" (grades 6-12); "Measuring Helps an Electrician Wire an Apartment" (grades 4-6); "An Electrical Engineer Plans an Electrically Safe Outdoor Concert" (safety) (grades 5-9); "Electricity from Wind, Water \& Sunlight" (grades 4-8), which includes a lab activity kit; and "Risk: Taking Chances, Making Choices" (grades 6-10)

When available, the above materials are free of charge from many electric utilities. Contact the education specialist at your local utility. Materials also may be purchased directly from the publisher.

\section{Environmental Hazards Management Institute (EHMI)}

10 Newmarket Road

P.O. Box 932

Durham, NH 03824

(603) 868-1496

Fax: (603) 868-1547

E-Mail: ehmiorg@aol.com

Web: http://www.EHML.org

An independent, nonprofit environmental, health, and safety education and research institute working to promote environmental responsibility at home, in the workplace, and in the community through education and relationship building.

Offers environmental, health, and safety education and outreach materials for adults and children. Topics include recycling/buy recycled; energy efficiency/conservation and indoor air quality; household chemical product management; water quality; lead poisoning prevention; used oil recycling; composting; and more. The balanced, well-researched information is offered in a variety of formats including enviro-wheels (slide-charts); tabloid publication for school children; bookcovers; color-in activity books; color-in posters; and videos. There is a fee for all educational materials. Discounts are available on bulk orders. A free catalog is available.

\section{EV Media}

612 Colorado Avenue, Suite 111

Santa Monica, CA 90401

(310) 394-3980

Fax: (310) 394-3539

An educational publishing company providing electric vehicle-related materials.

Provides publications and activity kits on electric vehicles (EV) for schools and the general public. Materials range from color booklets for secondary school students to teacher guides, electric vehicle model kits, and discussion 
leader guides free from many electric utilities with EV programs. Materials cover electric vehicles, electricity, energy efficiency and conservation. Titles include Electric Car, a 16-page color booklet (for grades 7 through 12); the 128-page Teacher's Electric Car Book, everything a teacher needs to conduct a unit on electric vehicles; "The Electric Flyer Model Kit," which includes everything needed to build a working, table-top size model electric vehicle; and "The Electric Vehicle Classroom Kit," which includes a classroom set of color booklets; the Teacher's Electric Car Book, and five to eight "Electric Flyer Model" kits. The battery/charger option for the EV "Classroom Kit" includes five to eight rechargeable 1.5 volt AA Ni-cad batteries and a four-unit battery charger. Contact your electric utility electric vehicle department for these materials, which are often offered at no cost to educators.

\section{Exxon Company, U.S.A.}

Public Affairs

P.O. Box 2180

Houston, TX $77252-2180$

(713) $656-8758$

Fax: (713) 656-6267

Web: http://www.exxon.com

Oil company department that responds to public inquiries pertaining to energy and environmental issues.

Offers a collection of scientific reports and brochures that document the environmental recovery of Prince William Sound, Alaska, following the 1989 Valdez oil spill. Also available is the 22-minute video, "Scientists and the Alaska Oil Spill;" and the video and lesson plan on artificial reefs, "Aquariums Without Walls;" and a comic book entitled Mickey \& Goofy Explore the Universe of Energy. The materials are free, but quantities are limited.

Flexible Packaging Educational Association

1090 Vermont Avenue, N.W., Suite 500

Washington, DC 20005

(202) $842-3880$

Fax: (202) $842-3841$

E-Mail: fpa@flexpack.org

Web: http://www.flexpack.org

A trade association of manufacturers and suppliers of flexible (or nonrigid) packaging, supporting educational efforts on the purpose of packaging and its role in the first " $R$ " of waste management -- reduction.

Offers Less Waste in the First Place: Six Lessons on Packaging, Flexible Packaging and Source Reduction, a lesson guide on packaging, free to educators. Appropriate for students in grades 4 through 10, the lessons discuss the historic, scientific, social, and environmental considerations involved in the design, development, and disposal of packaging. Included are instructions for a "hands-on" packaging design contest for students and suggestions on how to 
involve the local community. The lesson plan also features a listing, which can be used as a handout, of other resources and an explanation of common myths surrounding packaging and garbage.

\section{Florida Energy Office}

Department of Community Affairs

2555 Shumard Oak Boulevard

Tallahassee, FL 32399-2100

(850) $488-2475$

Fax: (850) 488-7688

E-Mail: jacqueline.klein@dca.state.fl.us

Web: http://www.state.Fl.us/comaff/hcd/CBBoard/current.htm\#energy

The State's point of contact on all energy-related matters, issues, and programs.

Focuses on solar energy and conservation. Renewable Energy Activities for Middle Grades, lesson plans for students in grades 6 through 8, is available. Solar and Energy Conservation Projects for Students is available to elementary school teachers. Another publication, Energy Research Projects Guide, assists students in their selection of energy topics for science fair projects. Single copies are free of charge to Florida teachers and students.

\section{Florida Power \& Light Company \\ Energy Encounter 6501 South Ocean Drive \\ Jensen Beach, FL 34957 \\ 1-(877) FPL-4FUN (toll free) \\ (561) $467-7000$ \\ Fax: (561) 467-7565}

Web: http://www.fpl.com/encounter

\section{A regulated investor-owned utility that serves more than 3 million customers in Florida.}

Provides limited free energy educational resources within the Florida Power 8 Light service area. Sponsors an electrical safety poster contest for elementary and middle schools. Offers special environmental education presentations on manatees and sea turtles, and a series of environmental education pamphlets. Operates the Energy Encounter visitors' center at the St. Lucie Nuclear Power Plant on Hutchinson Island. The center is open to the public and offers physical and environmental science presentations to school groups as well as teacher workshops for educators. Presentations meet the science objectives for Florida. Also offers environmental tours of the Barley Barber Swamp and Turtle Beach Nature Trail. 


\section{Florida Solar Energy Center (FSEC)}

1679 Clearlake Road

Cocoa, FL 32922-5703

(407) $638-1000$

Fax: (407) 638-1010

Web: http://www.fsec.ucf.edu

The energy institute for the State University System, FSEC's mission is to conduct research on alternative energy technologies, ensure the quality of solar energy equipment, and educate people about their energy options.

Offers free publications on solar water heating, energy-efficient buildings, transportation, and lighting. Provides workshops and information packets to students, teachers, and energy professionals.

Foodservice \& Packaging Institute, Inc.

1550 Wilson Boulevard, Suite 701

Arlington, VA 22209

(703) $527-7505$

Fax: (703) 527-7512

E-Mail: foodserv@crosslink.net

Web: http://www.fpi.org

A nonprofit trade association for manufacturers, suppliers, and distributors of foodservice disposable products. These products consist of single-use cups, plates, bowls, bags, cutlery, trays, hinged-lid "clamshell" containers, and other paper, plastic, and aluminum items. Foodservice \& Packaging Institute, Inc. (FPI) supports the environmentally responsible manufacture, distribution, use, and disposal of foodservice disposables.

FPI has just published Foodservice Disposables: Facts and Fun, a middleschool Environmental Science resource full of information and student activities. Also offers one-page issue sheets appropriate for middle and high school students on "Environment," "Sanitation," and "Lifestyle." These explain the importance of foodservice disposable products to today's consumers. Single copies of these FPI publications are free to educators. Contact FPI for larger quantities. For additional information about other publications, visit the Web site above. 


\title{
Frey Scientific
}

A Division of Beckley Cardy

100 Paragon Parkway

Mansfield, $\mathrm{OH} 44903$

$1-(888)$ 222-1332

Fax: 1-(888) 454-1417

E-Mail: gribbend@BC-mail.com

Web: http://www.BeckleyCardy.com

A full-line supplier of educational materials, equipment, and supplies for science, designed for students from kindergarten through college.

Offers a general science catalog that includes over 75 pages of products for earth science and ecology study. Product line consists of books, charts and posters, videos and video discs, software, kits, games, manipulatives, general supplies and equipment, and more. Products are available for a fee; catalog is free of charge.

\author{
General Atomics Sciences Education Foundation \\ General Atomics \\ 3550 General Atomics Court \\ San Diego, CA 92121-1194 \\ (619) 455-3335 \\ Fax: (619) 455-3379 \\ E-Mail: pat.winter@gat.com \\ Web: http://www.fusioned@gat.com
}

\section{A research and development center for high-technology systems.}

Offers information to high school and middle school teachers and students regarding current U.S. and worldwide nuclear fusion research that is aimed at understanding fusion science and its role in providing an energy resource for tomorrow's needs. Available materials include a 20-minute video, "Fusion: Creating a Star on Earth" and a high school teachers guide and workbook. A full size color poster is also available. These items are available free, while supplies last. Requests for the teachers guide and poster must be sent on school letterhead. In addition, General Atomics will send out at no charge material explaining the operation and safety of high temperature gas-cooled reactors which are meltdown proof and convert about 50 percent of the fission energy to electricity. When large atoms are fissioned by neutrons, energy is released. Nuclear reactor plants use this energy to make steam or hot gas to drive turbines which drive generators to make electricity. 


\section{Geothermal Education Office}

664 Hilary Drive

Tiburon, CA 94920

$1-(800) 866-4436$

(415) $435-4574$

Fax: (415) $435-7737$

E-Mail: geo@marin.org

Web: http://geothermal.marin.org

A nonprofit educational organization serving teachers and students nationwide to increase awareness and understanding of geothermal energy.

Provides free booklets, posters, fact sheets, and selected geothermal industry publications (some in class sets). Available for a fee are a high-school level and an elementary-school level video with transcript and glossary; and a 90-page geothermal curriculum for grades 4 through 8 . The curriculum, endorsed by the National Science Resources Center, covers the geology, history, and uses of geothermal energy, placed in the context of today's energy needs. Includes. copy-ready student information pages; science experiments; math, language, arts, and social studies activities; a glossary; and other suggested resources. $\quad 59$

\section{GPU Energy}

Community Initiatives Department

\section{Pottsville Pike}

P.O. Box 16640

Reading, PA 19640-0001

Web: http://www.gpukids.com

Headquartered in Reading, PA, GPU Energy serves 68 counties throughout New Jersey and Pennsylvania. GPU Energy is a subsidiary of GPU, Inc., an investor-owned electric utility based in Parsippany, NJ.

Provides free energy and electrical safety education resources for all grade levels on the gpukids.com Web site. The site features a variety of information that includes school-to-work initiatives, downloadable teacher modules, interactive curricula, lesson plans, and activities. A new Video Streaming Library allows teachers to select a video instantly on careers and energy related topics. Students can use the Web site to research energy topics, play in the arcade, send a post card, enter a contest or to see "watts" going on at GPU. Some materials on the gpukids.com web site are limited to educators in the GPU Energy service area. 
Hawaiian Electric Company, Inc.

Education \& Consumer Affairs Division

900 Richards Street

Honolulu, HI 96813

(808) $543-7511$

Fax: (808) 543-7412

Web: http://hei.com

An investor-owned electric utility that serves the island of Oahu in Hawaii.

Provides free teaching materials to educators in the areas served by Hawaiian Electric and its subsidiaries Maui Electric Company and Hawaii Electric Light Company. Services include classroom programs, career programs, resources for educators, certified workshops for educators, video, and classroom literature for kindergarten through grade 12. "Hawaii's Electric Century," an education module for Hawaiian history classes, is available for use in grades 4,7 , and 11 .

Houston Lighting \& Power Company

Community Relations/Educational Services

1111 Louisiana

P. O. Box 1700

Houston, TX 77251

(713) $207-1111$ or $(713) 207-7579$

Fax: (713) 207-9892

E-Mail: lucretia-ahrens@hlp.com

Web: http://www.hlp.com

An investor-owned electric utility, headquartered in Houston, serving a 5,000-square-mile area on the Texas Gulf Coast.

Provides free educational services to kindergarten through grade 12 educators in the Houston Lighting \& Power service area. Services include classroom presentations, films, video tapes, publications, and activity booklets for students. Resources and newsletters for educators and teacher in-service training, as well as teacher workshops, are also available. In addition, curriculum supplements are available on science and social studies topics and on electricity safety and fuel sources. New "Electric Universe" Internet Resource for Teachers and Students can be found at the Web site listed above. 
Illinois Department of Commerce and Community Affairs

Office of Coal Development and Marketing

325 West Adams, Room 300

Springfield, IL 62704-1892

(217) $782-6370$

Fax: (217) 785-2618

E-Mail: bantonini@commerce.state.il.us

Web: http://www.ILCOMMERCE.com/

A State coal program committed to the continued and expanded use of Illinois' coal resources in environmentally safe and economically viable ways.

Provides materials on coal production, distribution, usage, research, development, and demonstration of clean coal technologies. Materials available include: Coal is Cool Activity Book, with 60 coal-related puzzles, which is recommended for kindergarten through grade 4 and a teacher's guide for kindergarten through grade 4; Illinois Coal Teacher's Guide, developed with lesson plans and hands-on activities for grades 5 through 8; a video, "Kids, Coal and the Environment;" and a poster, What's Coal Got 'To Do With You? Illinois Coal...Energizing the $21^{\text {st }}$ Century, an integrated teaching resource manual covering the formation, history, and uses of coals as well as clean coal technologies. All materials are free. Coal awareness and education efforts target the general public through the media, schools, and special programs in an attempt to diffuse myths regarding coal and to disseminate sound, scientific information. An order form listing all the various publications is available upon request.

Independent Petroleum Association of America

Information Services Department

1101 16th Street, N.W.

Washington, DC 20036

(202) $857-4722$

Fax: (202) $857-4799$

E-Mail: treardon@ipaa.org

Web: http://www.ipaa.org

The national association representing independent crude oil and natural gas explorers/producers.

Provides for a fee an annual yearbook of statistics on the crude oil- and natural gas-producing States. The Oil \& Natural Gas Producing Industry In Your State compiles exploration and production statistics for each producing State in a simple manner, suitable for junior high and senior high school students. 
Indiana Department of Education

Office of Program Development

Center for School Improvement \& Performance

Room 229, State House

Indianapolis, IN 46204-2798

(317) $232-9186$

Fax: (317) 232-9121

E-Mail: cmcgrew@mgmt.perdue.edu

A State education agency that provides primary school and secondary school teachers with staff development programs and curricular assistance in environmental and energy education.

Provides energy, economics, and environmental curricular materials and workshops to kindergarten through grade 12 classroom teachers across Indiana. The Energy, Economics, and the Environment publication consists of case studies supported by classroom activities, actions, and issues. Completing the Cycle -. It's Up to Me contains 55 interdisciplinary lessons that focus on recycling and the environment. This curriculum for kindergarten through grade 8 was written by classroom teachers from Frankfort Community Schools and Crawfordsville Community Schools. The Phase I booklet is designed for use in kindergarten through grade 3 , and Phase II is for use in grades 4 through 8 . A minimal charge will be assessed for each publication. A list of other environmental and energy education materials is available upon request.

The Institute for Chemical Education (ICE)

Department of Chemistry

University of Wisconsin-Madison

1101 University Avenue

Madison, WI 53706-1396

$1-(800) 991-5534$

(608) $262-3033$

Fax: (608) 265-8094

E-Mail: ICE@chem.wisc.edu

Web: http://ice.chem.wisc.edu/ice

A nonprofit educational organization that provides chemistry resources and graduate-level workshops for kindergarten through grade 12 teachers to better integrate hands-on chemistry into their classrooms.

Provides chemistry education materials and workshops to kindergarten through grade 12 teachers throughout the world. The publications, kits, and workshops are designed to help teachers include hands-on science activities in their everyday classrooms. ICE's Topics in Chemistry series provides background chemical and environmental information on everyday topics. Topics include: 
Acid Rain--a brief history of acid precipitation; the sources of gases that cause acid rain and their conversion to acid in the atmosphere; details of the effects of acid precipitation on the environment; and available alternatives to reduce emissions that contribute to acid rain. Acid Rain, Experimental Supplementfive experiments showing the effects of acid rain on the environment, using easy-to-find materials; notes on presentation and curriculum integration are included. Ozone--the chemistry, uses, and importance of ozone and chlorofluorocarbons; a history of theories involving their interactions in the atmosphere; the effect of ozone depletion on life; examination of changes in public policy; and the response of industry.

\section{Integrated Waste Services Association}

1401 H Street, N.W., Suite 220

Washington, DC 20005

(202) $467-6240$

Fax: (202) 467-6225

Web: http://www.wte.org

Integrated Waste Services Association (IWSA) represents companies that use trash to produce energy as part of a community's integrated solid waste plans. Waste-to-energy facilities use waste to generate enough energy to power 1.3 million homes.

IWSA offers WasteWorld, a middle school curriculum addressing environmental, economic, and energy-related issues associated with municipal solid waste management. Originally developed with the support of DOE's National Renewable Energy Laboratory, this multimedia simulation presents a balanced view of source reduction, recycling, waste-to-energy, and land-filling, enabling students to recommend solid waste management plans for their communities. The updated package includes a slide show, interactive computer software for both Macintosh and Windows on CD-ROM, revised student activities and teacher's guide, glossary, and resources to supplement student research. Write or call or visit the Web site for more information.

Jacksonville Electric Authority (JEA)

21 West Church Street

Jacksonville, FL 32202

(904) 632-5200

Fax: (904) 632-6335

Web: http://www.jea.com

A municipal electric utility serving over 320,000 customers in Jacksonville, FL, and vicinity.

Provides free energy educational resources (booklets, posters, kits, audio/visual materials, etc., for kindergarten through grade 12) to schools within the JEA service area. Services include student and teacher materials, speakers, power plant tours, teacher seminars with affiliates: Pelotes Island Preserve, Tree Hill, and the University of North Florida. A free fact sheet that describes the services and materials is available upon request. 
Johnson Controls, Inc.

Academy of Energy Education

507 E. Michigan Street

Milwaukee, WI 53202

(414) $274-5574$

Fax: (414) 274-5030

E-Mail: michelle.l.tanem@jci.com

Web: http://www.johnsoncontrols.com/cg

Provides facility services and building control system solutions to meet the specific needs of all types of nonresidential buildings, which include training staff to operate equipment more efficiently, installing, maintaining, and servicing HVAC controls and mechanical systems, lighting controls, and life safety systems; performance contracting; and complete outsourcing operations.

Offers, in partnership with the National Energy Foundation (NEF), a curriculum-enhancing program that promotes energy education in kindergarten through grade 12-plus and expands into a school-to-work transition experience. Designed to encourage students to explore energy usage and its impact on the environment, the Academy of Energy Education programs include: Energy Fun for kindergarten through grade 3; Energy Fundamentals for grades 4 through 6; Energy Action Patrol for grades 5 through 8; Energy Action Teams for grades 6 through 9; and Energy Action Technology for grades 9 through 12. For high school and college students, the Academy features career exploration and externships in exchange for college credits granted by Utah State University. Each program contains a Polaroid camera and film packet to integrate visual learning aspects and the Energy Action Challenge for personal application of energy conservation. For more information, call your local Johnson Controls office or NEF at 1-800-616-TEAM.

Keep America Beautiful, Inc.

1010 Washington Boulevard

Stamford, CT 06901

(203) 323-8987

Fax: (203) 325-9199

E-Mail: kabinc@aol.com

Web: http://www.kab.org

A national nonprofit public education organization that is dedicated to empowering citizens to take a personal role in enhancing the community environment.

Offers educational materials for use in kindergarten through grade 12. Waste in Place, a curriculum supplement for educators of kindergarten through grade 6 , introduces children to responsible waste handling in over 30 hands-on lesson plans; and Waste: A Hidden Resource, a curriculum supplement for educators of grades 7 through 12, provides an overview of solid waste and encourages students' investigation and decisionmaking through role-playing in a mock crisis. Both are available for a fee. Other resources include Plastics 
Recycling By The Numbers, a classroom activity guide designed to teach students in grades 3 and 4 about plastic and its uses, the Plastic Container Coding System, and how to separate plastics for recycling; Mister Rogers' Activity Book for Young Children, which provides lessons on reuse and recycling; and "Pollution Pointers For Elementary Students," a one-page fact sheet which describes 24 things children can do. "Woody's Wise Waste Handling Tips for Kids" provides simple projects children can perform at home and in the classroom. These are available for a nominal fee. A free materials catalog is available upon request. Free samples of lesson plans and other publications are available at the above Web site.

Kids For A Clean Environment (Kids F.A.C.E.)

P.O. Box 158254

Nashville, TN 37215

1-(800) 952-3223

Fax: (615) 333-9879

E-Mail: kidsface@mindspring.com

Web: http//www.kidsface.org

\section{A nonprofit children's environmental organization.}

Provides free membership to children and teachers. Included with membership is the membership guide Our World, Our Future: A Kids Guide to Kids for a Clean Environment; a membership certificate; and a subscription to the bimonthly newsletter Kids F.A.C.E. Illustrated. Material focuses on environmental topics and offers proactive projects that can be performed at home or at school. Their current project is the One In A Million Program. One million children will plant one million trees by the year 2000 . For instructions, send a self-addressed stamped envelope to the above address.

Kissimmee Utility Authority (KUA)

Office of Communications

P.O. Box 423219

Kissimmee, FL 34742-3219

(407) $933-7777$

Fax: (407) 933-1761

E-Mail: cgent@kua.dst.fl.us

Web: http://www.kua.com

A municipal electric utility serving over 45,000 customers in Osceola County, Florida.

Provides free energy educational resources (coloring books, booklets, calendars, posters, kits, audio/visual materials, etc., for use in kindergarten through grade 12) to schools within the KUA service area. Services include student and teacher materials, speakers' bureau, power plant and energy control center tours, and teacher seminars with neighboring utilities. A free color brochure highlighting the services and materials is available upon request. 72 
The Learning Works

P.O. Box 6187, Dept. NEIC

Santa Barbara, CA 93160

(805) 964-4220

Fax: (805) 964-1466

E-Mail: lesattlw@aol.com

Web: http://www.thelearningworks.com

A publishing firm specializing in children's educational books.

Publishes educational activity books for youth ages 4 to 17 . Energy-related titles include: Weather, Electricity, Environmental Investigations; Science Works; Earth Book for Kids: Activities to Help Heal the Environment; My Earth Book; and Likeable Recyclables. These books are available from school supply stores, bookstores, or the publisher. A free catalog is available upon request.

Midwest Renewable Energy Association

P.O. Box 249

Amherst, WI 54406

(715) 824-5166

Fax: (715) 824-5399

E-Mail:mreainfo@wi-net.com

A grassroots private nonprofit educational organization dedicated to promoting renewable energy and energy efficiency through education and demonstration.

Offers special workshop series for teachers, children, and the general public. Hosts the Midwest Renewable Energy Fair every June at the Portage County Fairgrounds in Amherst, WI. This annual event features workshops, exhibits, speakers, a model home, renewable energy home tours, alternatively fueled vehicle showcase, regional Junior Solar Sprint competition, entertainment, and more. Offers year-round workshops on renewable energy and energy efficiency. ReNews, a quarterly newsletter is available for a minimal fee.

Mineral. Information Institute (MII)

47517 th Street, Suite 510

Denver, CO 80202

(303) 297-3226

Fax: (303) 295-6463

A nonprofit educational organization providing free resources and contacts to support classroom teachers.

Provides mineral and energy information at no cost to teachers. Companies and other organizations may purchase MII materials at a nominal cost. Materials include posters, lessons, activities, and referrals to other sources 
providing free or low-cost educational information. The purpose of all materials is to increase awareness that Everything We Have and Everything We Use Comes From Our Natural Resources. MII sponsored and continues to support revisions to the high school integrated science textbook, Global Science: Energy, Resources, Environment. Teachers should write on school letterhead indicating grade(s) taught. For a fee, a Go Kit for Classroom Speakers is also available.

Minnesota Department of Public Service

121 7th Place East, Suite 200

St. Paul, MN 55101-2145

(612) $296-5175$

Fax: (612) 296-0201

E-Mail: infocenter@dpsv.state.mn.us

Web: http://www.dpsv.state.mn.us

A State energy office which protects the public in utility rate and quality of service matters, provides a range of energy information, and promotes conservation and renewable resource development.

Provides a wide range of energy conservation materials (primarily brochures and fact sheets) targeted to residential, commercial, and industrial audiences. This information is designed to encourage specific conservation practices and to increase public awareness of energy/environmental issues. Some of these free materials may be appropriate for students in grades 8 through 12. More direct education efforts are geared toward Minnesota home builders and community energy auditors. The Department's Energy Information Center has a full-time staff to answer consumers' energy-related questions and to provide individualized advice as needed.

National Aeronautics and Space Administration (NASA)

300 E Street, S.W., Code FE

Washington, DC 20546-0001

Web: http://www.hq.nasa.gov/education

A Federal agency with programs to advance the Nation's education goals through expanding and enhancing the scientific and technological competence of all students and educators.

NASA On-line Resources for Educators provide current educational information and instructional resource materials to teachers, faculty, and students. A wide range of information is available, including science, mathematics, engineering, and technology education lesson plans, historical information related to the aeronautics and space program, current status reports on NASA projects, news releases, information on NASA educational programs, and useful software and graphics files. Educators and students can also use NASA resources as learning tools to explore the Internet, access 
information about educational grants, interact with other schools that are already on-line, participate in on-line interative projects, and communicate with NASA scientists, engineers, and other team members to experience the excitement of real NASA projects.

National Arbor Day Foundation

100 Arbor Avenue

Nebraska City, NE 68410

(402) $474-5655$

Fax: (402) 474-0820

E-Mail: mscribner@arborday.org

Web: http://www.arborday.org

A nonprofit education organization dedicated to tree planting, conservation, and environmental stewardship.

Provides free information on tree planting and care, including correctly planting windbreaks and shelterbelts, in the Conservation Trees and Trees for America brochures. Also has available for a nominal fee a book on Trees for Fuelwood: A Step Toward Energy Diversity, and, for elementary school-and middle school-age children, curriculum kits that stress the contributions made by trees and the importance of environmental stewardship. For samples of the free educational materials, including the Celebrate Arbor Day! booklet, and to receive information about the curriculum kits, write or call to request an Educational Materials Sampler.

\section{National Association of Conservation Districts (NACD)}

408 East Main

P.O. Box 855

League City, TX 77574-0855

1 -(800) 825-5547

(281) $332-3402$

Fax: (281) 332-5259

E-Mail: public affairs@NACDNET.org

Web: http://NACDnet.org

A nongovernmental nonprofit organization representing nearly 3,000 soil and water conservation districts and their State associations in the 50 States and U.S. territories. NACD serves its member districts as one voice, utilizing the force of local initiative and self-government, in the conservation and development of natural resources.

Sponsors conservation education recognition programs for primary school and secondary school teachers as well as a poster contest for students. Publishes and distributes educational materials about conserving soil and water and other natural resources. Free materials include an education catalog containing all educational products available from NACD and information about the contest. 
National Corn Growers Association

1000 Executive Parkway, \#105

St. Louis, MO 63141

(314) $275-9915$

Fax: (314) 275-7061

E-Mail: corninfo@ncga.com

Web: http://www.ncga.com

Actively represents the interests of producers of the nation's top grain crop. Membership includes over 30,000 growers in 48 states and 42 affiliated state corn grower organizations. NCGA's mission is to create and increase opportunities for corn growers in a changing world and enhance corn utilization and profitability.

Provides teachers with a free educational kit, "Corn - A National Renewable Resource," which includes materials that recognize corn as a reservoir of energy and a renewable substitute for products made from expendable fossil fuels. Components of the kit include 15 student tabloids, resource guide and activity sheets. Accompanying Teacher's Guides provide supplementary information and integration ideas. The World of Corn resource booklet, a statistical look at corn markets and trends, can also be requested separately and is provided free by contacting the association.

\section{National Cotton Council of America}

Education Materials

1918 N. Parkway

Memphis, TN 38112

(901) $274-9030$

Fax: (901) 725-0510

E-Mail: info@cotton.org

Web: http://www.cotton.org

A nonprofit commodity organization representing 25,000 producers and processors of raw cotton. The organization is dedicated to strengthening the cotton industry's ability to compete effectively and profitably in the raw cotton, oilseed and value-added product markets at home and abroad.

Provides for a nominal fee a variety of print and audiovisual materials on cotton, including a videotape about the highly successful and environmentally sound "National Boll Weevil Eradication Program." The tape, primarily for grades 3 through 12, includes a 3-minute program aired on the "Today's Environment" television series on the Discovery Channel. The eradication program uses an integrated approach for eliminating one of the U.S. cotton industry's major pests, such as plowing down cotton stalks after harvest, the strategic placement of traps baited with a pheromone (sex attractant), and the judicious application of crop protection products. 
National Energy Education Development Project (NEED)

P.O. Box 2518

Reston, VA 20195

(703) $471-6263$

Fax: (703) 471-6306

E-Mail: need@erols.com

Web: http://www.need.org/need

A national network of students, educators, and leaders in government and industry dedicated to providing comprehensive energy programming.

Through hands-on science, math, museums, drama, art, and music, students reach out to family and community with energy education programs that they have developed themselves. Memberships are available to teachers at little or no cost. Members can receive the following: the "Local Participation Kit" a curriculum packet filled with hundreds of activities; energy and leadership training workshops across the United States; a subscription to Energy Exchange magazine; the opportunity to order a variety of supplemental materials free of charge; and the chance to participate in the Annual Youth Awards Program -a program dedicated to recognizing the most creative and innovative energy programs in the United States. New activities for the 1998 school year include: The National Energy Survey, a web-based survey of students and adults on their attitudes and knowledge of energy. October 1998 will commemorate 25 years since the Oil Embargo; new activities and programs will be released to assist educators in remembering that event and in helping students understand America's energy picture, past, present, and future.

\section{National Energy Foundation (NEF)}

Resources for Education

National Office

5225 Wiley Post Way, Suite 170

Salt Lake City, UT 84116

(801) 539-1406

Fax: (801) 539-1451

E-Mail: nef@nef1.org

Web: http://www.nef1.org

A nonprofit educational organization providing educational resources and training services to educators.

Announces the establishment of the new NEF Academy. The Academy is a nationwide program of the Foundation which provides university graduate credit to educators for implementation of energy, environmental, and natural resources education in their classrooms. Academy course topics include energy conservation, rocks and minerals, and natural gas fundamentals and safety. Also included is the NEF award-winning Energy Action Patrol. Each course is independent study, with credit offered from accredited universities. New products available from NEF include two posters, "Out of the Rock," and "Electrotechnology: A Light on the Past, Present and Future:" Other new 
publications include for kindergarten through grade 3 , an activities guide entitled, Natural Gas Fun and Safety and an activities guide entitled, Thomas Edison and Electrotechnology. NEF currently has active educational partnerships with private and government entities nationwide, including an educational materials fulfillment program which provides free natural gas education materials to educators around the country. NEF also offers in-service support to sponsors and school districts. A free full-color catalog of educational resources is available free upon request.

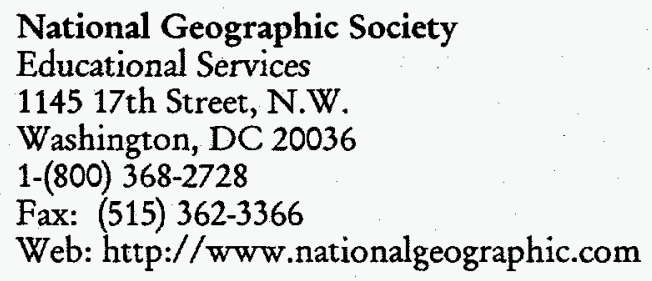

\section{A nonprofit organization.}

Provides educational materials designed for the kindergarten through grade 12 earth, physical, and environmental sciences curriculum. Materials include videos, books, atlases, globes, software, maps, posters, Wonders of Learning kits, Picture Pack transparency sets, interactive videodiscs, and CD-ROMs. The National Geographic Kids Network, a telecommunications-based science curriculum for elementary/and middle school-grade levels is also available. Free catalogs are available upon request.

The National Hydropower Association

122 C Street, N.W.

Washington, DC 20001

(202) $383-2530$

Fax: (202) 383-2531

E-Mail: Hydroinfo@aol.com

Web: http://www.Hydro.org

An association dedicated to building greater public awareness of the advantagesof hydropower as our Nation's most plentiful renewable energy source.

Offers a variety of materials on the production of hydropower, hydro's economic and environmental benefits, and the issues facing the hydropower industry. Posters and educational curriculum are available at nominal cost. An annual conference is held every spring, featuring a variety of educational programs. NHA works closely with the U.S. Export Council for Renewable Energy, the Fund for Water and Energy Education, and other organizations dedicated to hydropower and other forms of renewable energy. Staff is available to answer specific questions and to help identify sources of additional information. 


\section{National Mining Association}

Education Department

113017 th Street, N.W.

Washington, DC 20036

(202) 463-2625

Fax: (202) 857-0135

E-Mail: csheppard@nma.org

Web: http://www.nma.org

A trade association representing producers of America's coal, metals, industrial minerals, and agricultural minerals; mining equipment manufacturers; and engineering, consulting, and financial institutions that serve the mining industry.

Provides educational materials on mining in the United States and the importance of minerals in our daily lives. A video, "Mining: Discoveries for Progress," is available on the Web at http://www.vpw.com. A brochure, What Mining Means to Americans, is available for a fee to the general public. Single copies are available free to a teacher requesting them on school letterhead. Other materials are available upon request.

National Network of Energy and

Environmental Education Professionals

302 West Hill Street

Champaign, II 61820

(217) 359-9442

Fax: (217) 359-9446

E-Mail: Educational_Dividends@compuserve.com

Web: http://www.leeric.lsu.edu/network/network.htm

A grass roots membership organization comprised of program managers in government, business, education and nonprofit organizations. Goal is to serve as an information coordinator and to promote the expansion of energy and environmental education.

Information is available on educational materials and activities in all aspects of energy and environmental areas. Assistance is available on questions regarding programs in your area, developing energy and environmental lessons, or integrating energy and environmental information into existing lessons. Network membership is available for a fee, which allows access to field-tested materials, projects and strategies which can be included in your program, assistance with curriculum development, evaluation, incorporating the arts or marketing your program. Members meet annually at a Networking Conference and information is exchanged through the organization's newsletter, Network News, the Network Home Page and through personal contacts. 
National Propane Gas Association

1600 Eisenhower Lane, Suite 100

Lisle, II 60532

(630) $515-0600$

Fax: (630) 515-8774

Web: http://www.propanegas.com

A national trade association comprising 3,600 companies representing all aspects of the propane industry.

Provides environmental, safety, and propane industry information in fact sheets, a coloring book, and an activity book. Also available are an Energy Costs Comparison Calculator and four propane gas student education kits: one for use in kindergarten through grade 3; in grades 4 through 6; in junior high school; and in high school.

National Rural Electric Cooperative Association

Government Relations Department

4301 Wilson Boulevard, CD10-222

Arlington, VA 22203

(703) $907-5717$

Fax: (703) $907-5516$

Web: http://nreca.org

A service organization based in Arlington, VA. Represents the Nation's 1,000 nonprofit consumer-owned rural electric systems, which provide electric service to more than 25 million people in 46 States.

Provides educational booklets and pamphlets aimed at junior and senior high school students (as well as adults). Publications include History of Rural Electrification; Energy and Electricity (includes a home safety audit); Facts About America's Rural Electric Systems; and Occupations in Rural Electrification. Publications are for sale. An order form for the materials is available upon request. 


\section{National Science Foundation}

Office of Legislative and Public Affairs

4201 Wilson Boulevard, Room 1245

Arlington, VA 22230

(703) $306-1070$

Fax: (703) 306-0157

E-Mail: nstw@nsf.gov

Web: http://www.ehr.nsf.gov

A Federal agency that supports basic science and engineering research and education.

National Science and Technology Week (NSTW), a collaborative effort of the National Science Foundation and corporate sponsors, features partnerships with community institutions (e.g., schools, libraries, museums, zoos); a special focus activity encourages parents to join their children in discovering science in their everyday activities and interests. Materials include an NSTW annual poster, "training activities" packets, and "sharing science" brochures that alert the public to scientific discovery. Activities and materials promote: (1) the sharing of information on science curriculum and education trends; (2) developing "Science Day" activities; (3) organizing community-wide contests or events; and, (4) recruiting scientific and technical personnel to advise children about careers.

\section{National Science Resources Center (NSRC)}

Arts and Industries Building, Room 1201

Washington, DC 20560

(202) $357-4892$

Fax: (202) 786-2028

E-Mail: outreach@nas.edu

Web: http://www.si.edu/nsrc

NSRC is operated by the Smithsonian Institution and the National Academy of Sciences/National Academy of Engineering/Institute of Medicine to improve the teaching of science in the Nation's schools.

Collects and disseminates information about exemplary science teaching resources, develops innovative science curriculum materials, and sponsors outreach activities to help school districts develop and sustain hands-on science programs. Relevant titles include: Resources for Teaching Elementary School Science, and Resources for Teaching Middle School Sciences, science resource guides; Electric Circuits, Magnets and Motors; The Technology of Paper; and Ecosystems, inquiry-centered curriculum units in the Science and Technology for Children (STC) elementary science program. 


\section{National Science Teachers Association}

Publications

1840 Wilson Boulevard

Arlington, VA 22201

1-(800) 722-NSTA

(703) $243-7100$

Fax: (703) 243-7177

E-Mail: pubsales@nsta.org

Web: http://www.nsta.org

The largest science teachers association in the United States, working to improve the quality of science education nationwide.

Publishes educational products and activity books for students from kindergarten through college. Titles include: Earth: The Water Planet; Water, Stones \& Fossil Bones; Ten-Minute Field Trips; Energy Sources and Natural Fuels; Taking Charge: An Introduction to Electricity; Water Matters; Middle Level Energy Series; Project Earth Science: Astronomy; Project Earth Science: Meteorology; Project Earth Science: Physical Oceanography; Project Earth Science: Geology; Earth At Hand; Decisions - Based on Science; Biodiversity; Carrying Capacity; Deforestation; Energy Sources and Natural Fuels Vol. 2; Evidence of Energy: An Introduction to Mechanics; Move with Science: Energy, Force \& Motion; and Teach With Databases: Toxics Release Inventory. These books are available for a fee. A free catalog is available upon request.

\section{National Wildlife Federation}

8925 Leesburg Pike

Vienna, VA 22184

(703) $790-4100$

Fax: (703) 790-4094

E-Mail: wildlife@nwf.org

Web: http://www.nwf.org

The Nation's largest nonprofit conservation education organization. The mission of the National Wildlife Federation is to educate, inspire, and assist individuals and organizations of diverse cultures to conserve wildlife and other natural resources and to protect the Earth's environment in order to achieve a peaceful, equitable, and sustainable future.

Publishes the magazines Your Big Backyard and Ranger Rick ${ }^{\otimes}$ for children and National Wildlife, and International Wildlife for adults; produces a free National Wildlife Week Kit for educators each year; produces Animal Tracks ${ }^{\otimes}$ Action Pack curriculum units for educators on Habitat, Water, Wetlands, Urban Communities, and The Northern Forest; conducts Animal Tracks teacher training workshops around the country; produces Animal Tracks resources online at http://www.nwf.org/atracks and a free Animal Tracks Current Events Hotline listserv for kindergarten through grade 12 educators; produces the annual Conservation Directory; and has a Schoolyard Habitats branch of the Backyard Wildlife Habitat ${ }^{3}$ program. Call for a free educator's packet. 
The Natural Gas Vehicle Coalition

1515 Wilson Boulevard, Suite 1030

Arlington, VA 22209

(703) $527-3022$

Fax: (703) 527-3025

E-Mail: kbatte@NGVC.org

Web: http://www.NGVC.org

A national trade association and commercialization organization supported by gas companies, natural gas vehicle equipment suppliers, local government agencies, and other companies committed to developing profitable, long-term markets for natural gas vehicles.

Acts as a clearinghouse for information on natural gas vehicles for members and the general public. General information packets and the Member Business Guide, a list of member equipment suppliers and the products and services they provide, are available free of charge. Also available for a nominal fee is "The Road to Clean Air," a 12-minute educational video which features actress Lindsay Wagner describing the virtues of natural gas vehicles.

\section{Natural Gas Supply Association (NGSA)}

805 15th Street, N.W., Suite 510

Washington, DC 20005

(202) $326-9300$

Fax: (202) 326-9330

E-Mail: clegates@ngsa.org

Web: http://www.renewable.org

http://www.hydrates.org

http://www.ngsa.org

http://www.naturalgas.org

A nonprofit trade association of domestic natural gas producers.

All materials provided by NGSA are contained on Web sites, grouped as follows:

http://www.renewable.org - contains information about initiatives that would mandate the use of renewable energy for electricity generation and how those initiatives would affect natural gas. Information about the positives and negatives of various forms of renewable energy is included. Also, there is NGSA material comparing the advantages and disadvantages of natural gas and renewables. Additionally, some forms of methane hydrates are renewable.

http://www.hydrates.org - contains extensive information about methane hydrates, a virtually unlimited source of natural gas now being investigated by scientists and companies around the world. Both general and research information is included. In addition, there is a special section for kindergarten through grade 12 students. 
http://www.ngsa.org - contains information about public policy issues of concern to natural gas consumers as well as to those employed in and interested in the industry. Issues covered include supply issues (royalty payments and field deliverability of natural gas), issues related to the Federal Energy Regulatory Commission (including the transmission and gathering of natural gas and the rates and regulations of interstate natural gas pipelines), distribution issues (retail competition at the consumer level) and demand issues (environmental regulations that prevent natural gas from being used to improve air quality and the use of natural gas to generate electricity). An annotated list of natural gas associations is included.

http://www.naturalgas.org - gives a complete educational overview of the entire natural gas industry, plus the role natural gas plays in the electricity industry. It does not contain policy issues from any particular point of view, but does contain descriptions developed by Federal agencies of federal gas policies.

New York State Geological Survey/State Museum

3136 Cultural Education Center

Albany, NY 12230-3136

(518) 474-5816

Fax: (518) 486-3696

E-Mail: rfakundi@mail.nysed.gov

The mission of the New York State Geological Survey is to make services available to all agencies and people of New York State; conduct geological research; and cooperate with agencies of other States, Federal Government, educational institutions, and industry in the discovery, analysis, and dissemination of geologic information.

Provides free educational leaflets for both students and teachers for kindergarten through grade 12. Provides a limited number of honoraria for college-level geological research in New York State. Conducts workshops and classes in geological sciences through the New York State Museum in Albany, NY. Produces geological maps and reports for both professionals and the general public. A catalog of publications is available free upon request.

The NoodleHead Network

107 Intervale Avenue

Burlington, VT 05401

$1-(800) 639-5680$

(802) $862-8675$

Fax: (802) 864-7135

E-Mail: noodlhed@together.net

Web: http://www.noodlehead.com

An educational video producer and distributor that creates videos from a kid's viewpoint. 
Produces and distributes educational videos for kids. Specializes in energyrelated video tapes for utilities and the kindergarten through grade 12 school market. Kids play an integral role in the creation of each tape - from scriptwriting to acting to editing. Titles include: "Simple Things You Can Do To Save Energy," "Simple Things You Can Do To Save Energy In Your School," and "KnuckleHead's Electrical Safety Series." Videos are available for purchase in VHS format or with duplication and broadcast rights. Free catalogs and preview copies of the videos are available upon request.

\author{
Northeast Sustainable Energy Association (NESEA) \\ 50 Miles Street \\ Greenfield, MA 01301 \\ (413) $774-6051$ \\ Fax: (413) 774-6053 \\ E-Mail: nesea@nesea.org \\ Web: http://www.nesea.org
}

The largest regional energy association in the United States, and a leading force in public and professional education, advocacy, and policy information.

Offers educational materials on the subject of sustainable energy choices as it relates to transportation, everyday choices, and the role of trees in the energy and carbon cycle. In particular, NESEA offers Getting Around Without Gasoline, an 8-chapter lesson set for middle school teachers and students free of charge; a 48-page booklet and teacher guide on sustainable choices for grades 4 through 7 entitled Choose Your Future: Adventure Game (free review copy); and Totally TREE-Mendous Activities for grades 3 through 6 for a fee; and free transportation resource packets for elementary and high school students.

In addition, NESEA coordinates the Northeast Junior Solar Sprints, and invites students from grades 5 through 8 to participate in a miniature solar car competition run by over 10 area coordinators from Maine to Washington, DC; organizes the annual NESEA American Tour de Sol, the electric vehicle championship, and invites high school students to build an electric or hybrid vehicle and enter the event, and also invites students of all ages to take a field trip to the event and receive a guided tour of the vehicles; offers workshops and conferences for educators on the educational materials and activities outlined above.

NESEA's Web site, eleven local chapters, and publications such as the Northeast Resource Guide, and the Northeast Sun magazine keep a vital and growing network of members informed on the latest information on sustainability as it pertains to energy production and use, buildings, and transportation. Contact NESEA to receive information on any of these offerings. 


\section{Northeast Utilities}

Community Relations-Educational Programs

P.O. Box 270

Hartford, CT 06141-0270

(203) $665-2752$

Fax: (860) 665-2023

Web: http://www.nu.com

An investor-owned electric utility serving Connecticut, western Massachusetts, and New Hampshire.

Provides educational services free to educators and organizations in the areas served by Northeast Utilities. Offers visits to information centers, tours, classroom presentations, nature trails and environmental education, speakers' bureau, safety presentations, video library, energy/nuclear energy curriculum and related literature, teacher workshops, and teaching kits. Booklets and posters for kindergarten through grade 12 are available. Also has pamphlets on home appliances, insulation, heating and cooling, and weatherization.

Connecticut Yankee Information E Science Center 362 Injun Hollow Road Haddam Neck, CT 06424-3099 1-(800) 348-INFO (CT only) (860) 267-9279

\section{Millstone Information \& Science} Center

278 Main Street

Niantic, CT 06357

1-(800) 428-4234 (CT only)

(860) 691-4670

Fax: (860) 691-4676

Northfield Mountain Recreation

E Environmental Center

99 Millers Falls Road

Northfield, MA 01360

1 -(800) $859-2960$

(413) 659-3714

Fax: (413) 659-4460
Public Service of New Hampshire Amoskeag Fishways Learning Center $1000 \mathrm{Elm}$ Street

P.O. Box 330

Manchester, NH 03105 (603) 626-3474

Web: http://www.psnh.com

The Science E Nature Center at Seabrook Station

Box 300, Route 1

Seabrook, NH 03874

1-(800) 338-7482 (New England only)

(603) 474-9521, Ext. 2727

Fax: (603) 474-9521, Ext. 2782 


\section{Northern Indiana Public Service Company}

Corporate Citizenship

ATTN: Educational Services

5265 Hohman Avenue

Hammond, IN 46320

(219) 647-5089

Fax: (219) 647-4010

E-Mail: mjtylka@nipsco.com

Web: http://www.nipsco.com

A regulated electric and natural gas public utility serving the northern third of Indiana.

Provides, free to primary school and secondary school educators within its service territory, power plant tours, films, videos, publications, and activity booklets.

\section{Northern States Power Company}

Community and Economic Development Department

414 Nicollet Mall (RS4)

Minneapolis, MN 55401

(612) 330-6677 (school-to-work)

(612) 330-6538 (speakers)

(612) $330-7981$ (tours)

(612) 330-7976 (energy safety demos)

An investor-owned electric and natural gas utility serving parts of Minnesota, Wisconsin, North Dakota, South Dakota and northern Michigan.

Provides educational services free to educators in the areas served by Northern States Power Company. Offers visits to two nuclear plant training centers and Minnesota's largest coal-fired plant; energy and environmental education curriculum; speakers' bureau; job shadowing; and career exploration.

\section{Nuclear Energy Institute}

1776 I Street, N.W., Suite 400

Washington, DC 20006-3708

(202) $739-8000$

Fax: (202) 785-4019

E-Mail: publications@nei.org

Web: http://www.nei.org

The nuclear energy industry's Washington-based policy organization.

Provides a variety of publications on nuclear energy issues, including the 
benefits of electricity generated by nuclear power, public opinion data on nuclear energy, and statistical data on nuclear energy. Complimentary packets of material on nuclear energy are available for students and teachers. For more information, contact the NEI Publications Office.

Nuclear Information and Resource Service

1424 16th Street, N.W., Suite 601

Washington, DC 20036

(202) $328-0002$

Fax: (202) 462-2183

E-Mail: nirsnet@igc.org

Web: http://www.nirs.org

\section{A nonprofit information clearinghouse.}

Furnishes fact sheets on nuclear waste, safety, general information, and alternative energy. Single copies are available. The NIRS Energy Audit Manual: How to Audit Campus \& City Buildings, is available for a fee, includes chapters on lighting efficiency, heating, and air conditioning designed to help students calculate energy and cost savings for their school (high school and above). Current information on nuclear industry and events is available, as well as a catalog of related articles.

\section{OG\&E Electric Services \\ Community Services \\ P.O. Box 321 MC 1204 \\ Oklahoma City, OK 73101 \\ (405) 553-3015 \\ Fax: (405) 553-3508 \\ E-Mail: pangbor1@oge.com \\ Web: http://www.oge.com}

An investor-owned electric utility serving parts of Oklahoma and western Arkansas.

Provides educational materials free to educators in the areas served by OG\&E Electric Services. Materials include films/videos, literature, multimedia kits with teacher/student materials. Activity booklets and a teacher resource guide are also available. 
Ohio Oil \& Gas Association

1718 Columbus Road, SW

P.O. Box 535

Granville, $\mathrm{OH} 43023-0535$

(740) $587-0444$

Fax: (740) 587-0446

E-Mail: tstewart@ohiolinks.com

Web: http://www.ooga.org

Formed in 1947 to protect, promote, foster and advance the common interests of those engaged in all aspects of the Ohio crude oil and natural gas producing industry. With a 1,400 membership, this is one of the largest organizations of its kind in the United States.

Offers the following materials: Drill Bits, a series of informational news articles concerning issues of public interest; Facts at a Glance, an informational brochure about the Ohio crude oil and natural gas industry; The Energist: Getting to Know Natural Gas (single copy); and The Energist: Getting to Know Petroleum (single copy). Also available is a list of several hundred products made from petroleum; and activities and puzzles designed for classroom use prepared by the Ohio Division of Geological Survey.

\section{Oklahoma Energy Resources Board}

3555 N.W. 58th, Suite 430

Oklahoma City, OK 73112

1-(800) $664-1301$

(405) $942-5323$

Fax: (405) 942-3435

E-Mail: oerb@oipa.com

Web: http://www.oerb.com

An oil and natural gas industry-funded state agency dedicated to energy education and restoring environmentally damaged orphaned and abandoned oil and gas production and exploration sites.

Provides to Oklahoma educators free of charge the following: teachers guides with classroom activities for Fueling Around and Fossils To Fuel, two sciencebased energy curriculum units for elementary and middle schools. Also sponsors 2-day teacher workshops free of charge (and reimburses school districts for substitute pay during workshops). Offers free of charge a statewide coordinated program entitled Petroleum Professionals in the Classroom. This interactive hands-on program is presented by oil and natural gas industry volunteers who bring energy facts to the classroom in 45-minute presentations. Also free of charge is an oilfield safety video, "Play It Smart!." Geared to middle school students, it explains the dangers of playing around oilfield equipment. It stars members of the Dallas Cowboys football team as well as other football teams. 


\title{
Omaha Public Power District
}

Consumer Relations Department

444 South 16th Street Mall

Omaha, NE 68102-2247

(402) 636-3747

Fax: (402) 636-3922

E-Mail: sjefferson@oppd.com

Web: http://www.oppd.com/

A public utility serving the electric needs of customers in eastern Nebraska.

Provides educational services free of charge to schools in the utility's service area. Services include classroom programs and speakers, career planning information, films/videos, tours of power plants and other facilities, and literature for students and teachers in all grades. Also provides information on Omaha Public Power District's Buddy Alert and Safetysaurus Programs. All materials available upon request.

\author{
Pacific Gas \& Electric Company \\ Customer Energy Management Department \\ 123 Mission Street, Room 2280, Mail Code H28L \\ P.O. Box 770000 \\ San Francisco, CA 94177 \\ (415) $973-8235$ \\ Fax: (415) 973-4961 \\ E-Mail: DFL2@pge.com \\ Web: http://www.pge.com
}

\section{An investor-owned utility serving more than 4 million residential} customers.

Provides the Energenius Educational Series, several complete curriculum programs focusing on energy efficiency and gas and electric safety education for grades 1 through 8 . Curriculum materials are provided at no cost to schools within the service territory and can be purchased by schools, utilities, and organizations outside Pacific Gas \& Electric's service territory. Energenius Educational Series comes complete with teacher curriculum guide and student activities for each student. The core of the series consists of multi-lesson classroom programs designed to engage students in active, age-appropriate learning and to relate to pace-setting curriculum standards such as those of the State of California. Games and activities can be used inside or outside the classroom and involve both young people and their families. 
PP\&L, Inc.

Education Relations/Community Affairs

Two North Ninth Street

Allentown, PA 18101-1179

(610) 774-6914

Fax: (610) 774-6503

Web: http://www.papl.com

\section{An investor-owned electric utility serving over one million customers.}

Provides energy and environmental education materials and programs to educators and students. This includes kindergarten through grade 12 curriculum. Nuclear Energy Seminar for Teachers (NEST) (worth 3 graduate credits), Energy and Environment Workshop (worth 1 graduate credit), Teaching Environmental Awareness (TEA) workshops, School-to-Career programs, electrical safety programs, a minigrant program for educators (up to 500 matching funding), a newsletter (Partners) for educators, Electric Go-Cart Competition for high school teams, and Let's Get Real real-life problem solving competition for middle and high school teams.

\section{Plastic Bag Association}

Plastic Bag Information Clearinghouse

1817 E. Carson Street

Pittsburgh, PA 15203

$1-(800) 438-5856$

Fax: (412) 471-9417

E-Mail: pbainfo@aol.com

Web: http://www.plasticbag.com

A consortium of the industry's leading manufacturers and suppliers who work together on industry issues and focus on promoting the functional and environmental benefits of plastic bags.

Provides educational resources for elementary and middle-school educators and information for consumers to increase public understanding of the facts related to plastic bags and the environment. "Don't Let a Good Thing Go to Waste" is an environmental education program for students in grades 2 through 5. Its interactive, interdisciplinary activites help students discover that they can make a difference in solving solid waste challenges by practicing the 3Rs: Reduce, Reuse and Recycle. The Grime Fighters activity poster helps elementary students take action against litter. "An Ounce of Prevention" middle-school curriculum and its poster-lesson plan on the Life of a Hamburger comprise a complete resource for teaching the elements of waste generation and waste prevention. The full nine-activity curriculum, developed with the National Science Teachers Association and Dow Chemical Company, helps students see how many resources are consumed and how much waste is generated in daily-life activities, such as eating a hamburger and choosing plastic or paper at the supermarket check-out counter. These activities help them realize the value of prevention when it comes to waste. 
Consumers can obtain information on the environmental benefits of plastic in the Life of a Plastic Bag brochure and can also locate the nearest plastic bag recycling collection site by calling the above number. The above Web site provides information on plastic bags and the environmental $3 R$ s, as well as the lesson plans for teachers and student puzzle activities with an Earth Day message. All materials are free.

Polystyrene Packaging Council

1801 K Street, N.W., Suite 600K

Washington, DC 20006

(202) $974-5321$

Fax: (202) 296-7354

E-Mail: pspc@socplas.org

Web: http://www.polystyrene.org

A nonprofit trade association dedicated to providing information about environmentally responsible methods of solid waste disposal for polystyrene and polystyrene recycling programs nationwide. Polystyrene Packaging Council's membership includes manufacturers of polystyrene resin, polystyrene foam and rigid food service packaging.

Offers The Polystyrene Packaging and the Environment Sourcebook, an easy-to-use reference guide for teachers that includes descriptions of available materials involving plastics and the environment. Offers age-specific classroom activities, which were prepared with the guidance of science teachers nationwide, that look at the role of plastics in our everyday lives. Also offers a general information brochure on polystyrene. One copy is available free of charge.

\section{Procter \& Gamble}

Educational Services

P.O. Box 14009

Cincinnati, $\mathrm{OH} 45250-0009$

(513) $945-8450$

Fax: (513) 945-8979

E-Mail: true.tb@pg.com

Public Affairs Division of a consumer products company.

Offers the free environmental education teaching kit "Planet Patrol" for grades 4 through 6. Materials teach students how to be a part of the solution to America's growing solid waste crisis. The teaching unit includes teacher's guide, student worksheets, and classroom poster. 
The Radon Group, Ltd.

P.O. Box 80653

Portland, OR $97280-1653$

(503) 245-7092

Fax: (503) 245-7092

Hands-on energy education program developers and distributors.

Provides easy-to-use "hands-on" kits meeting Education 2000 goals. Products work with all major science texts. Kits contain teacher guide, student masters, vocabulary, and hardware. Titles include the following: "Insulation Station Kit" on energy efficiency for grades 4 through 9; "Partnerships For A Work Ready America Kit," a conservation program for grades 10 through 12; "Generating Electricity Suitcase Kit" and a video "Zap Rap" on electricity safety for grades 3 through 8; "Nuclear Energy Kit" for grades 4 through 9; and "Solar Photovoltaic Suitcase Kit" and "Hydroelectricity - Water Power Suitcase Kit" for grades 3 through 8 . Custom teacher in-service programs are sponsored by participating utilities. Materials are provided free of charge by most utilities. Products may be purchased directly from the company. A free catalog is available.

Railroad Commission of Texas

P.O. Box 12967

Austin, TX 78711-2967

(512) 463-7114 (TEAM materials)

(512) 463-7006 (Alternative Transportation Fuels materials)

Fax: (512) 463-6702

E-Mail: hurt@rrc.state.tx.us

Web: http://www.rrc.state.tx.us (see energy education)

A State energy agency that regulates the oil and gas, alternative fuels and surface mining industries in Texas. The Commission serves Texans by: its stewardship of natural resources and the environment, its concern for personal and community safety, and its support of enhanced development and economic vitality.

Provides educational materials free to Texas teachers (kindergarten through grade 12) during Texas Energy Awareness Month (TEAM) each September. Texas oil and gas materials include suggested lesson plans, black-line masters for bookmarks and bulletin boards, a speaker's bureau, and resource lists. A bimonthly TV show called "Energize Your Classroom" is available through TSTAR, the state education satellite network. This show provides information about free or low cost energy materials. A document entitled Energy and Environmental Texas Essential Knowledge \& Skills in Social Studies is available. Also provides free educational workshops and supplemental curriculum materials called, "Alternative Transportation Fuels" for secondary science teachers in Texas. These materials are correlated with TAAS and the Texas Essential Knowledge and Skills and are provided to participants in the workshops only. Materials include a video called "Way Cool Fuels," posters, 
a game and additional resources. Also includes multi-lesson units entitled "What is Energy?," "Fuels for Everything," "What are Alternative Transportation Fuels?," "Air Pollution and Health," "Dollars and Sense," and "Technology." A teacher's guide, glossary, bibliography and a list of additional resources are provided. Workshops will be offered across Texas. Participating teachers receive extra-duty pay or reimbursements for substitute fees. Alternative Transportation Fuels is a joint project of the Texas Railroad Commission, the Texas General Land Office, and the Texas Education Agency and is funded from grants from the U.S. Department of Energy, the Texas State Energy Conservation Office, and the Texas Alternative Fuels Council. Seven free teacher and student lessons are available from the above Web site (see energy education).

\section{Renewable Fuels Association}

One Massachusetts Avenue, N.W., Suite 820

Washington, DC 20001

(202) $289-3835$

Fax: (202) $289-7519$

E-Mail: etohrfa@erols.com

Web: http://www.EthanolRFA.org

\section{A national nonprofit association promoting domestically produced renewable ethanol as an alternative to imported energy sources.}

Provides general information and educational fact sheets free of charge on ethanol, a clean-burning, renewable fuel produced from agricultural feedstocks and wastes. Topics include "Ethanol and Clean Air," "Ethanol and the Economy," "Ethanol and Agriculture," "Ethanol vs. Imported Energy," "Ethanol's Performance as a Fuel," and "Future Opportunities." Additional information is available free of charge by visiting the above Web site or calling the above number.

\section{Renew America}

1400 16th Street, N.W., Suite 710

Washington, DC 20036

(202) 232-2252

Fax: (202) 232-2617

E-Mail: renewamerica@igc.apc.org

Web: http://www.crest.org/renew_america

\section{The Nation's source for environmental solutions.}

Promotes successful environmental programs to foster their replication and expansion. Publications available for purchase include the Environmental Success Index, a directory of more than 1,600 verified programs. Access to the index is also available free at the above Web site. Kids! Renew America is also available free of charge. 
Safe Energy Communication Council

1717 Massachusetts Avenue, N.W., Suite 805

Washington, DC 20036

(202) 483-8491

Fax: (202) 234-9194

E-Mail: seccgen@aol.com

A national nonprofit coalition fighting for environmentally safe, affordable energy.

Offers a free poster with everyday suggestions on how to save the Earth, and one on energy efficient lighting. Publications and graphics that deal with a variety of issues, including utility deregulation, nuclear power, nuclear waste dangers, global warming, energy efficiency and renewable energy, are available for a nominal fee. Titles include: Reinventing Electric Utilities; MYTHBusters \#10: International Nuclear Power; MYTHBusters \#9: Nuclear Power Economics; Power Boosters: Obio's Energy Efficiency Success Stories (Industrial); and, Home Power Boosters: Obio's Energy Efficiency Success Stories. Request a publications list for other titles.

\section{Science Screen Report}

1000 Clint Moore Road

Boca Raton, FL 33487-2806

1-(800) 232-2133

Fax: (561) 241-0707

E-Mail: allegro@ssrvideo.com

Web: http://ssrvideo.com

The only video tape program made available free of charge to schools through corporate sponsors.

An ongoing secondary and elementary video tape series that focuses on the most recent developments in science, technology, and engineering. Produced since 1970 with the active participation of the National Science Teachers Association, "Science Screen Report" (SSR) is designed to stimulate student interest in the challenges and opportunities of pursuing careers in science. More than 650 corporations currently sponsor "SSR" to 3,5000 school districts nationwide. Tapes become the permanent property of the school system to allow repeated use year after year. 


\section{Science Service}

1719 N Street, N.W.

Washington, DC 20036

(202) $785-2255$

Fax: (202) 785-1243

E-Mail: sciedu@scisvc.org

Web: http://www.sciserv.org/sciserv

The mission of Science Service is to advance the understanding and appreciation of science among people of all ages through publications and educational programs.

Science Service administers two youth programs. The Intel International Science and Engineering Fair (ISEF) is a competition for students in grades 9 through 12. Students participate in their regional and/or State ISEF-affiliated fair. Two individual student projects and one team project of up to three students are chosen to participate in the ISEF. Participants are eligible for scholarships, scientific field trips, summer research internships, and equipment. The Science Talent Search awards $\$ 205,000$ in scholarships to 40 finalists. Top prize is a $\$ 40,000$ scholarship. Participants must be seniors in high school. Students submit a report of an independent research project in the sciences, official entry form, transcript, test scores, and teacher recommendations. The submission deadline can be as early as late November, but no later than early December. For an official entry form and specific deadline, contact Science Service.

\section{Shell Oil Company}

Corporate Communications

P.O. Box 2463

Houston, TX $77252-2463$

\section{(713) 241-6161}

Web: www.countonshell.com

Oil company department that responds to public inquiries pertaining to energy and environmental issues.

Offers Oil, a booklet describing the origin of oil and its production, conversion to thousands of products, and distribution to customers around the world. Also available are $A$ Story of Achievement, a brief history of the Shell Oil Company, and Count on Shell Driving Safety booklets. Booklets are free of charge, but quantities are limited. 


\section{SME}

P.O. Box 625002

Littleton, CO $80162-5002$

1-(800) SME-3132

(303) $973-9550$

Fax: (303) 973-3845

E-Mail: smenet@aol.com

Web: http: //www.smenet.org

A nonprofit educational organization providing educational resources related to energy, minerals, and mining. The Society for Mining, Metallurgy \& Exploration, Inc., (SME) is the worldwide professional society for mining engineers.

Offers both free and for-sale materials including classroom resource guides, posters, videos, and computer programs. Also can provide teachers with contacts among SME members in most geographic locations who are willing to help in teaching about minerals and mining.

\section{Society of Automotive Engineers International \\ SAE Foundation \\ 400 Commonwealth Drive \\ Warrendale, PA 15096-0001 \\ 1-(800) 457-AWIM \\ E-Mail: awim@sae.org}

The SAE Foundation is dedicated to supporting the development of educational programs to improve mathematics, science, and engineering education, from the elementary grades through graduate school.

Provides A World in Motion II: The Design Experience (AWIM II), a series of two specially adapted engineering design challenges for grades 7 and 8 . Each challenge lasts eight weeks. AWMM II is a multi-disciplinary curriculum, which includes math, science, social studies, and technology education. The program is an integrated curriculum built upon a real life scenario. The goals of AWIM II are to improve the teaching and learning of science, mathematics and technology education through the integration of the disciplines. AWTM II is a program based on an engineering design experience, suitable for middle school students and teachers; to strengthen the collaboration between students in design teams and teachers in teaching teams; to mobilize members of the community as classroom volunteers in support of a curriculum experience. Please write or E-mail SAE to obtain information on how to receive a free copy of A World in Motion curriculum. 


\section{Solar Energy Industries Association}

122 C Street, N.W., 4th floor

Washington, DC 20001

(202) $383-2600$

Fax: (202) 383-2670

E-Mail: info@seia.org

Web: http://www.seia.org

A nonprofit national trade association which represents the photovoltaic and solar thermal manufacturers and component suppliers.

Publishes Renewable Energy Fact Sheets, which include information and classroom activities. Also produces Solar Science Activities, which includes dozens of classroom activities for grades 5 through 9, and Energy, Technology and Society, which is geared for high school students and provides information on alternative energy technologies. All are available for a fee. A free publications catalog is available upon request. CD-ROM educational modules are available through the Solar Energy Research and Education Foundation.

\section{Solar Now}

Beverly High School

100 Sohier Road

Beverly, MA 01915

(978) 927-9SUN

Fax: (978) $927-9191$

E-Mail: solar19@idt.net

Web: http://www.eren.doe.gov/solar now

A national nonprofit organization providing education about all forms of renewable energy to teachers, students, and environmentalists.

Provides programs for students and educators seeking hands-on renewable energy education. Based at one of the Nation's largest photovoltaic sites, our field study center also hosts a $10 \mathrm{~kW}$ windmill and an interactive classroom. Field trips may be arranged by calling the above number. The following are also offered: comprehensive teacher education workshops, summer internships for college students, a library of renewable energy activities, and student conferences. A desk-top publication, $A$ Curriculum Framework for Education in Environmental and Renewable Energy Science: Grades Pre-Kindergarten through $1^{\text {st }}$ Year College is available for a small fee. 


\section{Steel Recycling Institute}

680 Andersen Drive

Pittsburgh, PA 15220-2700

1-(800) $876-7274$

Web: http://www.recycle-steel.org

An industry association dedicated to promoting and sustaining steel recycling across the country.

Provides materials for primary, middle and secondary school educators. Materials include Nature's for ME, a preschool teacher's guide filled with nature-related interactive exercises; "Let's Recycle Together," a finger puppet and four coloring poster play scenes/stories for ages 4 through 7; "YES I CAN!," a video and teacher's guide for grades 1 through 3; "Earth Cycles," a cross-age teaching program for grades 8 through 12 and grades 3 through 5. The guide outlines 3 hands-on activities; "Roscoe's Totally Cycled World," a new middle school CD-ROM with interactive missions in science, language arts, math and social studies; and "Cycles for Science," high school curriculum supplements for Biology, Chemistry, Physics and Earth/Life Science, and a community volunteer activities guide to support the program. Information and prices are available through order forms. Additional materials such as activity sheets (black sheet masters), and a coloring poster are available. Please indicate grade level(s) for which materials or order forms are needed.

The Sugar Association, Inc.

110115 th Street, N.W., \#600

Washington, DC 20005

(202) $785-1122$

Fax: (202) 785-5019

Web: http://www.sugar.org

Established in 1943, the Sugar Association maintains an active role in informing the public about the role that sugar can play, in moderation, in a healthful diet. By creating public education programs with a variety of diet, health, nutrition, and fitness materials, the Association has worked to dispel misconceptions about sugar as well as provide opportunities for continued scientific research.

Offers Sugar Science: Photosynthesis to Food, a computer software package that explains the processes of photosynthesis and respiration as well as the role of plants in the food chain. This interactive software also provides experiments on sugar's functional role in food processing, including yeast interaction (baking), preservation (jams and preserves) and freezing (ice cream). The program, available for a fee, was reviewed by the National Science Teachers Association and is available in the following formats: Apple Ie, Apple IIGS, IBM, Macintosh, IBM Novell, and AppleShare. Accompanying the software is a teacher's manual that includes a user's guide for the software and explanations of the experiments, including objectives, additional data and definitions, and extension activities for students. Recommended for upper elementary/middle school students. 
Troll School and Library

100 Corporate Drive

Mahwah, NJ 07430

(201) $529-4000$

Fax: (201) 529-1862

Web:http://www.troll.com

A publishing firm specializing in children's books.

Publishes educational materials for students from Pre-Kindergarten through grade 8. Includes a complete line of science materials relating to life, earth and physical sciences. New Horizons, a Science, Technology and Environment Program, hands-on kits, and various supplemental books are available. Materials may be purchased from the publishers. Free catalogs are available upon request.

\section{Union of Concerned Scientists}

Two Brattle Square

Cambridge, MA 02238-9105

(617) $547-5552$

Fax: (617) 864-9405

E-Mail: ucs@ucsusa.org

Web: http://www.ucsusa.org

An independent, nonprofit organization of scientists and other citizens concerned about the impacts of advanced technology on society.

The Union of Concerned Scientists has created a unique alliance between many of the nation's leading scientists and thousands of committed citizens to address the most serious environmental and security threats facing humanity. Materials include books, fact sheets, and briefing papers on global warming, transportation policy, renewable energy, nuclear power safety, and sustainable agriculture. Fact sheets include: What is Global Warming?; Global Warming Hot Air: Some Popular Myths Dispelled; Cars and Trucks and Global Warming; Energy and Global Warming; and Global Warming Solutions. Free brochures include Solar Power, Energy on the Road, Nuclear Power, Renewable Energy and Developing Nations and the World Scientists' Call for Action on Global Warming. UCS's newest book is Energy Innovations: A Prosperous Path to a Cleaner Environment, which describes how we can reduce the threat of global warming while helping the economy. Teachers can purchase a 100-page multidisciplinary guide to teaching renewable energy in grades 7 through 12, as well as a collection of eight posters on renewables and a renewable energy slide show. 
University of Florida

Center for Economic Education

186 Norman Hall

Gainesville, FL 32611-2053

(352) 392-0971

Fax: (352) 392-9193

E-Mail: econed@coe.ufl.edu

Web: http://www.coe.ufl.edu/CEE/CEE.html

\section{A university center responsible for providing educational materials to} teachers.

Provides curriculum guides for teachers. Available for a fee are the Energy and Economics (high school); Resources and Energy (grades 2 and 3); and Resources and Energy (middle school) curriculum guides designed to give students a greater understanding of the connections between energy and economics. Bulk orders of 100 or more copies can be purchased at a discount.

University of Illinois at Urbana-Champaign

School of Architecture-Building Research Council (BRC)

1 East St. Mary's Road

Champaign, II 61820

$1-(800)$ 336-0616

Fax: (217) 244-2204

E-Mail: kgallghr@uiuc.edu

Web: http://www.arch.uiuc.edu/brc

\section{A nonprofit information clearinghouse and research center.}

Publishes 8-, 12-, and 16-page booklets on how to make homes comfortable, healthy, and energy efficient, which are appropriate for home owners and seniors in high school. BRC offers the following publications at a nominal fee: Home Inspection, which examines each home system -- plumbing, electrical, etc., and provides a checklist for buying a home; Lighting, which focuses on task, security, and general lighting; Energy Management, which outlines practical management plans for summer and winter; Insulating, which focuses on how to know what type and how much insulation is needed; Heating, which is about the various kinds of heating systems and how to select a system; Selecting Windows, which explains window options and energy savings by selecting wisely; and Moisture Condensation, which discusses how to keep moisture from making a home chilly and prone to water damage. A free publications catalog is available upon request. A complete set of 27 booklets is available for instructors and home owners. Bulk rates are available. 


\title{
U.S. Consumer Information Center
}

Pueblo, CO 81009

(719) $948-4000$

Fax: (719) 948-9724

E-Mail: Catalog.pueblo@gsa.gov

Web: http://www.pueblo.gsa.gov

Helps Federal agencies develop, promote, and distribute consumer information to the public through the Consumer Information Catalog.

Offers the free, quarterly Consumer Information Catalog containing listings of over 200 free and low cost Federal consumer publications on topics such as health, energy conservation, Federal benefits, money management, housing, child care, employment, small business, education, food and nutrition, and more. In addition, CIC also offers Lista de publicaciones Federales en espanol para el consumidor, which lists nearly 250 free Spanish publications available from various Federal agencies. A free catalog is available by writing to: Free Catalog, Pueblo, CO 81009.

Bulk copies are available to schools and nonprofit groups able to distribute 20 or more copies.

\author{
U.S. Department of Agriculture \\ Forest Service \\ Rocky Mountain Research Station \\ 240 W. Prospect Street \\ Fort Collins, CO 80526 \\ (970) 498-1500 \\ (970) 498-1719 (publications distribution) \\ Fax: (970) 498-1660 \\ Web: http://fsweb.rmrs.fs.fed.us
}

Forest Service research is intended to serve society by developing and communicating the scientific information and technology needed to protect, manage, and use the natural resources of forests and rangelands.

Provides copies of technical publications on ecosystem component interactions, resource management and protection, resource interactions, and people's values and interactions with ecological systems. Available publications include: Distribution of Abandoned and Inactive Mines on Forest Service Lands; Energy and Industries in National, Regional, and State Economies; and The Energy and Mineral Supply and Demand Situation Through 2045. 


\section{U.S. Department of Commerce}

National Oceanic \& Atmospheric Administration (NOAA)

Office of Public Affairs

14th \& Constitution Avenue, N.W., Room 6013

Washington, DC 20235

(202) $482-6090$

Web: http://www.noaa.gov

A Federal agency with programs to advance the Nation's science education goals by expanding and enhancing the scientific competence of all students, teachers, and the general public.

Provides free of charge to students, teachers, librarians, and the general public information about the earth's oceans and atmosphere including the topics of The Year of the Ocean, endangered marine mammals, severe and hazardous weather, El Niño, NOAA weather radio, coastal management, civilian satellites, and global warming. Information about NOAA's educational programs, like the Teacher at Sea, is also available from this office.

\section{U.S. Department of Education}

ERIC Clearinghouse for Science, Mathematics, and Environmental Education

1929 Kenny Road

Columbus, OH 43210-1080

$1-(800) 276-0462$

(614) $292-6717$

Fax: (614) 292-0263

E-Mail: ericse@osu.edu

Web: http://www.ericse.org

One of 16 ERIC clearinghouses, the ERIC Clearinghouse for Science, Mathematics, and Environmental Education (ERIC/CSMEE) develops, maintains, and makes accessible to the public the world's largest educationrelated database which includes over 850 items relating to energy education.

ERIC/CSMEE, sponsored by the National Library of Education, U.S. Department of Education, has as its primary function the acquisition and dissemination of printed materials related to science, mathematics, and environmental education. The information is indexed and abstracted for inclusion in two monthly publications, Resources in Education (RIE) and Current Index to Journals in Education (CIJE). RIE provides abstracts for a variety of educational materials; CIJE announces journal literature. In addition to acquiring and processing documents and journal articles, the ERIC/CSMEE staff produces digests and other documents. Digests are short publications (one page, front and back) on a single topic. Other publications include yearbooks, source books, reviews of research, instructional activity collections 
on broad topics, and collections of papers presented at national meetings. The Clearinghouse offers a variety of user services and maintains a full ERIC microfiche collection, RIE and CIJE reference collection, and a library collection of materials related to the scope areas. The Clearinghouse also provides a variety of electronic services on the Internet. The Clearinghouse World Wide Web server can be accessed at: http://www.ericse.org.

\section{U.S. Department of Education}

Office of Educational Research and Improvement (OERI)

P.O. Box 1398

Jessup, MD 20794-1398

1-(877) 4ED-PUBS

Fax: (301) 470-1244

Web: http://www.ed.gov

Provides information about education research, statistics, publications, and data sets.

Publishes a series of Helping Your Child books for parents. Included is Helping Your Child Learn Geography, which helps children look at the world in which they live, the effects of the environment on the way in which towns have developed, and the effects humans have had on the environment that have made areas livable. Other series topics include: Science, Math, History, Reading, Using the Library, Get Ready for School, Succeed in School, Responsible Behavior, and Being Healtby and Fit. All are available for a nominal fee. To obtain ordering instructions for all of the Helping Your Child books, write to Helping Your Child List, ED-PUBS, at the above address. Write to the above address to obtain the OERI Bulletin, a free quarterly listing of publications, programs, statistics, and grants.

\section{U.S. Department of Energy}

Argonne National Laboratory

Division of Educational Programs

9700 South Cass Avenue

Argonne, IL 60439

(630) $252-4114$

Fax: (630) 252-3193

E-Mail: hmyron@dep.anl.gov

Web: http://www.dep.anl.gov

\section{A DOE-funded multi-purpose national laboratory providing programs to promote science careers and improve science education.}

Provides three continuing programs for kindergarten through grade 12 teachers as follows: (1) The Argonne Community of Teachers, a local organization of teachers who have participated in Argonne programs in the past and who continue to work with the Laboratory to improve science education for schools in the Chicago area; (2) The Educational Networking Consortium (ENC) is a 
training and Internet access organization that attempts to train and connect Chicago area teachers to the Internet using a collection of dial-in sites in collaboration with the Illinois State Board of Education; and (3) NEWTON, The Science Teachers Bulletin Board, offers a place where teachers and students can discuss education and ask questions of practicing scientists. The bulletin board can be reached by Telnet at newton.dep.anl.gov Web site for all three programs: http://www.dep.anl.gov. See section Science, Technology and Education - Precollege Programs.

\section{U.S. Department of Energy}

Bioenergy Feedstock Development Program

Oak Ridge National Laboratory

P.O. Box 2008

Oak Ridge, TN 37831-6422

(423) $576-5132$

Fax: (423) 576-8143

E-Mail: are@ornl.gov

Web: http://www.esd.ornl.gov/bfdp

A DOE-funded program that supports research, analysis, and communication activities to foster the development and adoption of alternative fuels.

Provides free information on biomass, specifically fast growing trees and grasses, for use as raw materials for conversion to transportation fuels and electricity. The information is in the form of fact sheets, reports, and bibliographies. A newsletter, Energy Crops Forum, is published periodically. In addition, a World Wide Web/Internet service, the Bioenergy Information Network, contains full text of many of the reports, newsletters, and fact sheets and provides pointers to other places with related materials.

\section{U.S. Department of Energy}

Bonneville Power Administration

Community Education Program-AR

P.O. Box 3621

Portland, OR $97208-3621$

(503) 230-3709

Fax: (503) 230-5884

E-Mail: jhmcnamara@bpa.gov

Web: http://www.bpa.gov

Bonneville Power Administration (BPA) is both an electric utility and a Federal agency within DOE. Established in 1937, BPA markets electric power from Federal dams and other energy resources in the Pacific Northwest. BPA employs approximately 2,800 persons in Idaho, Montana, Oregon, and Washington. The majority work in the Portland-Vancouver metropolitan area headquarters and control center. BPA works with several business, school, and government agency partnerships. Many employees volunteer each year for various programs. 
Participates in a variety of education programs in the BPA four-State service area. Various programs, which are available in some areas for teachers and students from primary school through high school, include math and science enhancements, hands-on learning, worksite mentoring and apprenticeships, competitions, environmental education, tutoring, and others. Educational materials loaned or given free of charge to teachers in BPA's service territory (Oregon, Washington, Idaho and Western Montana) include curricula, hands-on activities, and storybooks; posters; videotapes; and exhibits. Topics covered are primarily electricity, energy conservation, and fish and wildlife

U.S. Department of Energy

Carbon Dioxide Information Analysis Center (CDIAC)

MS-6335, Building 1000

Oak Ridge National Laboratory

P.O. Box 2008

Oak Ridge, TN 37831-6335

(423) $574-0390$

Fax: (423) 574-2232

E-Mail: cdiac@ornl.gov

Web: http://cdiac.esd.ornl.gov

A DOE-funded program that provides information support to the international research, policy, and education communities for evaluation of issues related to climate change.

Provides reports and fact sheets, including a newsletter, CDIAC Communications, which describes CDIAC and DOE initiatives in global change research. Trends Online: A Compendium of Data on Global Change, a quick source of frequently requested data, is also available. Global Change Acronyms and Abbreviations is a publication providing a comprehensive listing of acronyms and abbreviations used in global change research, policy, and education settings. Glossary: Carbon Dioxide and Climate contains a glossary of $\mathrm{CO}_{2}$-related terms and tables of information related to $\mathrm{CO}_{2}$ and climate. These materials are suitable for middle school and high school students. All are free. A PC model on global energy - $\mathrm{CO}_{2}$ emissions is also available. The IEA/ORAU Long-Term Global Energy Economics Model with $\mathrm{CO}_{2}$ and $\mathrm{CH}_{4}$ Emissions is a PC-version of a computer model package, suitable for high school and college students, with a number of variables to interactively produce $\mathrm{CO}_{2}$ and $\mathrm{CH}_{4}$ emission scenarios for 1975 through 2100 . 


\section{U.S. Department of Energy}

Clean Cities Hotline

9300 Lee Highway

Fairfax, VA 22031

1-(800) CCITIES or (224-8437)

(703) $934-3068$

Fax: (703) 934-3183

E-Mail: ccities@nrel.gov

Web: http://www.ccities.doe.gov

The Clean Cities Hotline, sponsored by DOE, provides information on the Clean Cities Program -- a voluntary and cooperative effort to promote alternative-fuel vehicles.

Provides implementation and technical information on the DOE's Clean Cities program. Helps communities convert to alternative-fuel vehicles through coordination planning. Also provides general information on the Clean Cities Program, lists of involved cities and participants, as well as technical and regulatory information of use to Clean Cities, such as funding for alternative-fuel vehicles and information on the Clean Air Act and Energy Policy Act. Remains in direct contact with the Clean Cities Program Directors, DOE regional offices, and involved Clean Cities. The Hotline is available between 9 a.m. and 6 p.m., Eastern standard time. The toll-free 800 number is available to callers in the United States only.

\section{U.S. Department of Energy}

Energy Efficiency and Renewable Energy Clearinghouse (EREC)

P.O. Box 3048

Merrifield, VA 22116

1-(800) DOE-EREC or (363-3732)

Fax: (703) 893-0400

E-Mail: doe.erec@nciinc.com

Web: http://www.eren.nrel.gov

A DOE-funded energy information service responding to public inquiries on the use of renewable energy and energy conservation.

Provides information on renewable energy and energy-efficient technologies to consumers, teachers, and students. Maintains lists of organizations that will supply educators with energy-related booklets, audio-visual materials, software, bibliographies, project contacts, kits, and equipment. Publications suitable for primary school and secondary school students are available. Teachers and librarians may request activity lists, bibliographies, and background materials. Publications are free. 
U.S. Department of Energy

Federal Energy Technology Center

P.O. Box 10940

626 Cochrans Mill Road

Pittsburgh, PA 15236-0940

(412) $892-4913$

Fax: (412) 892-4152

E-Mail: wildman@fetc.doe.gov

Web: http://www.fetc.doe.gov

\section{A Federal fossil energy research facility.}

The Federal Energy Technology Center has campuses in Morgantown, West Virginia and Pittsburgh, Pennsylvania. Each site hosts a Regional Science Bowl and offers workshops to assist teachers in the local school systems. Free material for grades 3 through 6 that include extensive activities and teacher lesson plans are available. The materials include a booklet entitled Coal: Energy for Home and Community. The booklet describes laboratory activities, support information, discussion ideas, and overheads for viewgraphs on coal, solar, and wind energy sources.

\section{U.S. Department of Energy \\ Los Alamos National Laboratory \\ Science Education Program Office \\ MS F671 \\ Los Alamos, NM 87545 \\ (505) $667-8680$ \\ Fax: (505) 665-6871 \\ E-Mail: dgill@lanl.gov \\ Web: http://www.education.lanl.gov}

\section{A DOE-funded national laboratory.}

Offers 25 different educational programs for students, teachers and the public, for elementary through university levels. They include teacher enhancement workshops, student participation programs, technology integration, and curriculum development, in areas of science, engineering, math and technology. Some programs are national in scope, while others are regional or local. Each of the programs is described at the above Web site address.

Products available include: Science at Home, a book of science experimental activities for elementary and middle school students and parents to do together using commonly available materials; Risks, Rewards and Responsibilities, a curriculum module for high school teachers that uses the subject of radiation to look at the broader issue of risk assessment; and Hydrogen and the Materials of a Sustainable Energy Future, a notebook of experiments and demonstrations for teachers that were presented at the National Educator's Workshop: UPDATE 96 . Other materials may be available from time to time, and are announced on the Web site. 
U.S. Department of Energy

National Alternative Fuels Hotline

9300 Lee Highway

Fairfax, VA 22031

1-(800) 423-1DOE or $(423-1363)$

(703) 934-3069

Fax: (703) 934-3183

E-Mail: hotline@afdc.nrel.gov

Web: http://www.AFDC.DOE.GOV

The National Alternative Fuels Hotline (NAFH) is sponsored by DOE to assist the general public and interested organizations in improving their understanding about alternative transportation fuels.

Provides information on vehicle conversion technology, refueling station locations, and Federal alternative fuel programs. Free publications and data are available on alternative fuel technology, legislative and regulatory changes, and other issues concerning the alternative transportation fuel industry. In addition, NAFH works directly with the National Renewable Energy Laboratory's Alternative Fuel Data Center(AFDC). Data on vehicle emissions, performance, fuel economy, maintenance, and more are available through the AFDC. For more on alternative fuels and the AFDC, call NAFH's toll free number. 144

\section{U.S. Department of Energy}

National Energy Information Center (NEIC)

Energy Information Administration

1000 Independence Avenue, S.W.

EI-30 - Room 1F-048

Washington, DC 20585

(202) $586-8800$

Fax: (202) 586-0727

E-Mail: infoctr@eia.doe.gov

Web: http://www.eia.doe.gov

NEIC is the dissemination service of DOE's Energy Information Administration, which is responsible for developing energy data, analyses, and forecasts that help enhance public understanding of energy issues.

Available free of charge is the Energy INFOcard, a quick reference providing the most recent annual domestic and international energy data; the Electricity InfoCard, featuring recent electricity data in graphic form; Energy Education Resources: Kindergarten through 12th Grade; and Energy Information Sheets, a booklet comprising one-page capsules on such energy topics as petroleum, natural gas, coal, and renewable energy. All four products are available on EIA's World Wide Web site, which also features hundreds of links to other energy-related sites; an E-Mail subscription service for EIA press releases and other synopses of energy topics; an energy quiz; an interactive query system that allows you to tap directly into selected EIA data; an energy calendar listing schedules for future EIA publications and other energy events; and EIA publications and data bases covering the various energy sources. 


\section{U.S. Department of Energy}

National Low Level Waste Management Program

EM-35/Cloverleaf

Office of Environmental Management

19901 Germantown Road

Germantown, MD 20874-1290

(301) $903-7177$

Fax: (301) 903-7451

A Federal program providing both general and special technical assistance to States and regions to establish an effective nationwide system for the disposal of commercial low level radioactive waste.

Provides general information on low level radioactive waste management through short fact sheets, a booklet with answers to frequently asked questions on low level radioactive waste disposal, and brochures on what constitutes commercial low level waste; concepts for disposal of low level waste; and low level radioactive waste basics.

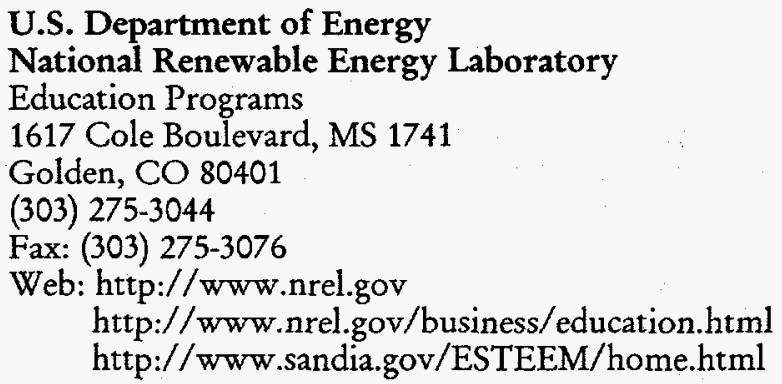

A DOE-funded national laboratory specializing in renewable energy and energy efficiency research and technologies.

Supports kindergarten through grade 12 science education and undergraduate research focusing on energy efficiency and renewable energy. Manages and supports numerous local and national science programs for both students and teachers, including the Junior Solar Sprint, a program for students in grades 6 through 8 to design and build a model solar car. Also is a resource for teachers and students looking for information, project ideas, lessons and reference materials on renewable energy and energy efficiency topics. 


\section{U.S. Department of Energy}

Office of Civilian Radioactive Waste Management

National Information Center

600 Maryland Avenue, S.W., Suite 695

Washington, DC 20024

1-(800) 225-NWPA

(202) $488-6720$

Fax: (202) 488-6721

Web: http://www.rw.doe.gov

A Federal program established to manage and dispose of the Nation's spent nuclear fuel and high level radioactive waste.

Furnishes a curriculum, Science, Society, and America's Nuclear Waste, to educators free of charge. The four-unit curriculum, designed for use in grades 8 through 12, contains materials for both students and teachers. Student materials include readings, review exercises, and activities. For teachers, supplemental teaching aids include video tapes, computer software, and viewgraphs. Also available is general information on the Civilian Radioactive Waste Management Program, including fact sheets, brochures, video tapes, and a semi-annual newsletter. All publications and video tapes are free upon request.

\section{U.S. Department of Energy}

Office of Nuclear Energy, Science and Technology

Office of Management and Administration, NE-10

Washington, DC 20585

(301) $903-1634$

Fax: (301) 903-1637

E-Mail: rosalyn.bowman@hq.doe.gov

Web: http://www.ne.doe.gov

Public Information Office for the Office of Nuclear Energy, Science and Technology. Responds to public inquiries about DOE's civilian nuclear energy program.

Offers energy educational materials, including historical and current factual data on nuclear energy. Pamphlets discuss such issues as the nuclear fuel cycle and civilian uses of nuclear energy. Available publications include: The History of Nuclear Energy, Atoms to Electricity, The Harnessed Atom, and several others. Also provides a booklet listing nuclear power plants, with operating data, and an education video tape on nuclear power and other energy sources. All publications are free. 


\section{U.S. Department of Energy}

Office of Scientific and Technical Information (OSTI)

P.O. Box 62

Oak Ridge, TN 37831

(423) $576-8401$

Fax: (423) 576-2865

Web: http://www.osti.gov

DOE OSTI collects, preserves, and disseminates the scientific and technical information resulting from the Department of Energy's research and development and environmental programs. The scientific and technical information produced through DOE and its predecessor agencies includes the bulk of recorded knowledge about nuclear energy and much about other forms of energy. OSTI provides access to over 3 million items in four major on-line information systems. OSTI also acquires domestic and international information through partnerships with U.S. agencies and over 110 countries and international organizations.

Provides pamphlets on various energy-related subjects as available and as directed by the program offices. Many publications are free. Also provides electronic access to departmental information through the DOE Home Page at the World Wide Web Server URL http://www.doe.gov on the Internet. For more information contact the Web site listed above.

U.S. Department of Energy

Pacific Northwest National Laboratory

University and Science Education Programs

P.O. Box 999, Mail Stop K1-72

Richland, WA 99352

(509) $375-2800$

Fax: $(509$ 375-2576

Web: http://www.pnl.gov/education

A DOE-funded national laboratory. Pacific Northwest National Laboratory (Pacific Northwest), puts science and technology to work to solve energy and environmental problems. Pacific Northwest focuses on research and development related to waste management, environmental restoration, global environmental change, energy, and national security.

Offers a variety of university and science programs that integrate research and education and support science education reform. Our education partnerships connect the human and technical resources of the Laboratory with students and teachers in elementary, middle, and high schools; technical/community colleges; and students and faculty at the university undergraduate and graduate levels. Provides opportunities for students and faculty to:

- participate in hands-on science and technology research as it is conducted in a research laboratory;

- participate in projects that investigate scientific and technological challenges; 
- update technical skills and understanding as well as renew enthusiasm for chosen scientific or engineering research;

- work with Laboratory scientists and engineers in an interdisciplinary team environment; and

- use state-of-the-art equipment not commonly found in most schools or colleges/universities

U.S. Department of Energy

Western Area Power Administration

P.O. Box 3402

Golden, CO 80401

(303) 275-1739

Fax: (303) 275-1616

E-Mail: buntin@wapa.gov

Web: http://www.energy.wsu.edu/org/western/

A DOE power marketing administration encompassing all or parts of 15 western States.

Provides contact points with WAPA's customers regarding on-going energy educational efforts on conservation and renewable energy for students from kindergarten through grade 12. For information, call the Energy Services Manager in any of the following cities: Billings, Montana, (406) 247-7392; Loveland, Colorado, (970) 490-7227; Phoenix, Arizona, (602) 352-2655; Sacramento, California, (916) 353-4490; and Salt Lake City, Utah, (801) 524-5506, or the Power Marketing Support Office in Golden, Colorado. 152

\section{U.S. Department of the Interior}

Bureau of Land Management (BLM)

1849 C Street, N.W.

Washington, DC 20240

(202) 452-5128 (Public Affairs)

(202) 452-0378 (Minerals Outreach Coordinator)

Fax: (202) 452-0399

Web: http://www.blm.gov/

A regulatory agency responsible for the management of a wide variety of resources on public lands. These resources include wildlife habitat, recreational values, cultural and historic sites, scenic, and wilderness areas as well as more than 60 types of minerals produced from public lands.

Provides materials on energy and mineral resources found on Governmentowned land. BLM has an active program for presentation of energy and minerals sciences, especially as they relate to the public lands. Exhibits may be arranged for professional functions or fairs. Presentations at local schools or youth gatherings can be arranged through any BLM office or through the Minerals Outreach Coordinator in Washington, DC. Demonstration areas 
showing preservation and reclamation techniques may be used as field trips for students. Also offers several videos on preservation of ecosystems and reclamation. Pamphlets, brochures, maps, fact sheets, environmental studies, and statistical summaries are available free upon request or for a minimal charge. BLM is also active in the preservation of old mining towns, and tours of these "ghost towns" may be arranged. BLM also has management responsibility for the Nation's newest national monument in Utah, the GrandStaircase-Escalante.

\section{U.S. Department of the Interior}

Minerals Management Service (MMS)

1849 C Street, N.W.

Washington, DC 20240

(703) $787-1080$

Fax: (703) $787-1010$ or $(703) 787-1186$

Web: http://www.mms.gov

MMS is a regulatory agency responsible for balancing energy and mineral resource development with protection of environmental resources on the U.S. Outer Continental Shelf.

Provides informational materials on gas, oil, mineral, and environmental resources in the ocean. Available materials include color photo posters, brochures, fact sheets, statistical summaries, technical reports, newsletters, environmental studies, and professional papers. Most material is free upon request, but quantities may be limited. MMS has an extensive color slide collection, and arrangements may be made for loans or duplications at cost. Most information is suitable for upper grade levels. Offices in Washington, DC; New Orleans, Louisiana; Camarillo, California; and Anchorage, Alaska, can arrange for presentations at local schools on the work conducted at MMS and on geology, environmental science, engineering, resource management, international activities, and related topics. Several video programs are available on loan, including an interactive video. MMS professionals have worked with schools to develop their energy and environmental resource curricula. Call or write for further information and referral or to ask for a catalog of publications. In addition, there is more information on MMS' Internet site. 
U.S. Environmental Protection Agency (EPA)

Information Resources Center, 3404

401 M Street, S.W.

Washington, DC 20460

(202) 260-5922

Fax: (202) 260-6257

E-Mail: public-access@epamail.epa.gov

Web: http://www.epa.gov

Information Resources Center for EPA. Responds to public inquiries about environmental issues and EPA programs. Also serves as the main referral point for the Agency.

Provides limited free material on drinking water, air quality, pesticides, radon, indoor air, Superfund, wetlands, and other environmental topics, to walk-in visitors. Will order documents to be mailed directly to callers.

Videodiscovery, Inc.

1700 Westlake Avenue N., Suite 600

Seattle, WA $98109-3012$

1-(800) 548-3472

(206) $285-5400$

Fax: (206) 285-9245

Web: http://www.videodiscovery.com

An educational software publisher.

Developer and publisher of multimedia programs for kindergarten through college-level science education. Specifically, the company publishes interactive science videodiscs, CD-ROMs, and computer software, such as STS Science Forums; Understanding Earth; Chemistry at Work; Science Sleutbs; and Physics at Work. The company is dedicated to improving science instruction through the advancement of educational technologies. A free catalog of products is available upon request.

Water Environment Federation

601 Wythe Street

Alexandria, VA 22314-1994

1-(800) 666-0206

(703) 684-2400

Fax: (703) 684-2492

E-Mail: public_education@wef.org

Web: http://www.wef.org

A not-for-profit technical and educational group of water quality experts with more than 41,000 members located in all 50 States and around the world. 
Publishes The Water Sourcebook, with over 60 hands-on classroom activities; the Water Environment Curriculum Program, including units on wastewater (also available in Spanish), surface water, groundwater (also available in Spanish) and water conservation. Many of the water quality experts act as classroom resources through the WEF Adopt-A-School program. Local members choose to "adopt" schools by providing guest speakers, presentations, and tours of water treatment plants, plus videos and other special resources. For more information on these and all of WEF's public education materials and brochures, call the toll free number.

\section{Waverly Light and Power}

1002 Adams Parkway

P.O. Box 329

Waverly, IA 50677

(319) 352-6251

Fax: (319) 352-6254

A municipal utility serving electric needs of the community.

Provides educational services free to educators within its service territory. Services include generating plant tours, classroom presentations, and purchased reference materials for kindergarten through grade 12.

\section{Westinghouse Electric Company}

\section{Energy Systems}

Communications Department

P.O. Box 355, Bay E575

Pittsburgh, PA 15230-0355

(412) $374-6803$

Fax: (412) 374-3272

E-Mail: kendr1lm@westinghouse.com

Web: http://www.westinghouse.com

A company dedicated to providing high quality products, services, technology, systems, and management in nuclear energy, as well as advanced energy and process control systems.

Provides energy-related materials to all who are interested, especially to teachers and to students who will make our energy decisions in the future. One copy of each booklet is available free of charge. However, for larger quantities, there is a fee. Materials available are: a simulated uranium fuel pellet; Electricity from Nuclear Energy; Nuclear Energy Glossary; Questions Kids Ask About Energy, Radiation Booklet; and Component Illustrations (color prints). For more information, you may contact the Communications Department of the Energy Systems Business Unit. 
Wisconsin Public Service Corp.

600 N. Adams

P.O. Box 19002

Green Bay, WI 54307-9002

(920) 433-5543

Fax: (920) 433-5741

Web: http://www.wpsr.com

WPSC provides electricity, natural gas, and energy products to more than 400,000 customers in an 11,000 square-mile area of Northeast Wisconsin and Upper Michigan. In addition to our corporate headquarters in Green Bay, we operate fossil, nuclear, and hydroelectric generating plants and have 19 customer centers throughout our service territory.

Provides a wide array of free energy-related videos, presentations, publications, and teaching kits to educators kindergarten through grade 12, students and community groups in the WPS service area. Our materials emphasize safety, energy management, environment, and renewable energy. Other services include tours, scholarships for teachers and students, school-to-work opportunities, speakers bureau, teacher workshops, and electric car demonstrations. Write or call to receive a complete list of our education programs. 


\section{SUBJECT INDEX}

The subject index is arranged alphabetically by specific energy terminology.

References are to the organization number, the number that follows each entry.

\section{COAL}

American Coal Foundation, 6

Baltimore Gas and Electric

Company (BGE), 21

California Energy Commission, 25

Center for Energy and Economic Development, The (CEED), 27

Charles Edison Fund, 30

City Public Service (CPS), 32

Dayton Power \& Light Company, 38

E2: Environment \& Education, 41

Educational Development

Specialists, 46

Energy Source Education Council, 47

Enterprise for Education, Inc., 48

GPU Energy, 60

Houston Lighting \& Power

Company, 62

Illinois Department of Commerce and Community Affairs, 63
Indiana Department of Education, 65

Jacksonville Electric Authority (JEA), 68

Kissimmee Utility Authority (KUA), 72

Mineral Information Institute (MII), 75

National Energy Education

Development (NEED), 82

National Energy Foundation (NEF), 83

National Geographic Society, 84

National Mining Association, 86

National Science Teachers

Association, 92

Northern Indiana Public Service

Company, 100

Northern States Power Company, 101

OG\&E Electric Services, 104

PP\&L, Inc., 109

Railroad Commission of Texas, 114 
SME, 121

U.S. Department of Agriculture

Forest Service, 132

U.S. Department of Education

ERIC Clearinghouse for Science, Mathematics, and Environmental Education, 134

U.S. Department of Energy

Federal Energy Technology Center, 142

National Energy

Information Center

(NEIC), 145

U.S. Department of the Interior

Bureau of Land

Management (BLM), 153

Wisconsin Public Service Corp., 160

\section{ELECTRICITY}

Alliance to Save Energy, The, 2

America Forest Foundation, 8

American Association for

Vocational Instructional Materials, 4

American Chemical Society, 5

American Coal Foundation, 6

American Nuclear Society, 10

American Public Power

Association, 13
American Wind Energy

Association, 16

Bakken Library and Museum,

The, 20

Baltimore Gas and Electric

Company (BGE), 21

California Energy Commission, 25

Center for Energy and Economic Development, The (CEED), 27

Center for Renewable Energy \& Sustainable Technology (CREST), 28

Channing L. Bete Publishing Co., Inc., 29

Charles Edison Fund, 30

City Public Service (CPS), 32

City Utilities of Springfield, 33

Culver Publishing, 37

Dayton Power \& Light Company, 38

Disney Educational Productions, 40

E2: Environment \& Education, 41

Edison Electric Institute (EEI), 44

Edison Plaza Museum, 45

Educational Development

Specialists, 46

Energy Source Education Council, 47

Enterprise for Education, Inc., 48 
EV Media, 50

Florida Energy Office, 53

Florida Power \& Light Company, 54

Florida Solar Energy Center (FSEC), 55

Frey Scientific, 57

Geothermal Education Office, 59

GPU Energy, 60

Hawaiian Electric Company, Inc., 61

Houston Lighting \& Power Company, 62

Illinois Department of Commerce and Community Affairs, 63

Indiana Department of Education, 65

Integrated Waste Services

Association, 67

Jacksonville Electric Authority (JEA), 68

Kissimmee Utility Authority (KUA), 72

Learning Works, The, 73

National Energy Education

Development (NEED), 82

National Energy Foundation

(NEF), 83

National Geographic Society, 84 i National Hydropower

Association, The, 85

National Propane Gas

Association, 88

National Rural Electric

Cooperative Association, 89

National Science Resources

Center (NSRC), 91

National Science Teachers

Association, 92

Natural Gas Supply Association

(NGSA), 95

NoodleHead Network, The, 97

Northeast Sustainable Energy

Association (NESEA), 98

Northeast Utilities, 99

Northern Indiana Public Service

Company, 100

Northern States Power Company, 101

Nuclear Energy Institute, 102

Nuclear Information and Resource

Service, 103

OG\&E Electric Services, 104

Omaha Public Power District, 107

Pacific Gas \& Electric Company, 108

PP\&L, Inc., 109

Radon Group, Ltd., The, 113 
Safe Energy Communication Council, 117

Science Service, 119

Society of Automotive Engineers International, 122

Solar Now, 124

U.S. Department of Education

ERIC Clearinghouse for Science, Mathematics, and Environmental Education, 134

\section{U.S. Department of Energy}

Bonneville Power

Administration, 138

Clean Cities Hotline, 140

Energy Efficiency and Renewable Energy Clearinghouse (EREC), 141

National Alternative Fuels Hotline, 144

National Energy

Information Center

(NEIC), 145

Western Area Power

Administration, 152

Union of Concerned Scientists, 128

University of Illinois at Urbana-

Champaign, 130

Videodiscovery, Inc., 156 i Waverly Light and Power, 158

Westinghouse Electric Company, 159

Wisconsin Public Service Corp., 160

\section{ENERGY}

\section{EFFICIENCY/ENERGY}

CONSERVATION

Air \& Waste Management Association (A\&WMA), 1

Alliance to Save Energy, The, 2

America Forest Foundation, 8

American Chemical Society, 5

American Council for an

Energy-Efficient Economy

(ACEEE), 7

American Nuclear Society, 10

American Petroleum Institute, 11

American Public Power

Association, 13

American Solar Energy Society, 14

Aseptic Packaging Council, The, 19

Baltimore Gas and Electric

Company (BGE), 21

\section{Bronx Zoo/Wildlife Conservation} Park, 23

Bullfrog Films, 24 
California Energy Commission, 25

Center for Renewable Energy \& Sustainable Technology (CREST), 28

Channing L. Bete Publishing Co., Inc., 29

Charles Edison Fund, 30

City Public Service (CPS), 32

Culver Publishing, 37

Dayton Power \& Light Company, 38

Disney Educational Productions, 40

E2: Environment \& Education, 41

Edison Electric Institute (EEI), 44

Educational Development

Specialists, 46

Energy Source Education Council, 47

Enterprise for Education, Inc., 48

Environmental Hazards

Management Institute (EHMI), 49

EV Media, 50

Florida Energy Office, 53

Florida Power \& Light Company, 54

Florida Solar Energy Center (FSEC), 55
Frey Scientific, 57

General Atomics Sciences

Education Foundation, 58

Geothermal Education Office, 59

GPU Energy, 60

Hawaiian Electric Company, Inc., 61

Houston Lighting \& Power

Company, 62

Indiana Department of Education, 65

Integrated Waste Services

Association, 67

Jacksonville Electric Authority

(JEA), 68

Johnson Controls, Inc., 69

Kissimmee Utility Authority (KUA), 72

Learning Works, The, 73

Midwest Renewable Energy Association, 74

Mineral Information Institute (MII), 75

Minnesota Department of Public Service, 76

National Energy Education

I Development (NEED), 82

National Energy Foundation (NEF), 83 
National Geographic Society, 84

National Network of Energy and Environmental Education

Professionals, 87

National Science Teachers

Association, 92

National Wildlife Federation, 93

NoodleHead Network, The, 97

Northeast Sustainable Energy

Association (NESEA), 98

Northeast Utilities, 99

Northern Indiana Public Service Company, 100

Northern States Power Company, 101

Nuclear Information and Resource Service, 103

OG\&E Electric Services, 104

Omaha Public Power District, 107

Pacific Gas \& Electric Company, 108

PP\&L, Inc., 109

Radon Group, Ltd., The, 113

Renew America, 116

Safe Energy Communication

Council, 117

Science Service, 119
Solar Energy Industries

Association, 123

Solar Now, 124

Steel Recycling Institute, 125

Troll School and Library, 127

U.S. Consumer Information Center, 131

U.S. Department of Education

ERIC Clearinghouse for Science, Mathematics, and Environmental Education, 134

U.S. Department of Energy

Bonneville Power

Administration, 138

Energy Efficiency and Renewable Energy Clearinghouse (EREC), 141

National Energy Information Center (NEIC), 145

National Renewable Energy Laboratory, 147

Office of Scientific and Technical Information (OSTI), 150

Pacific Northwest National Laboratory, 151

Western Area Power Administration, 152 
Union of Concerned Scientists, 128

University of Florida, 129

University of Illinois at Urbana-

Champaign, 130

Videodiscovery, Inc., 156

Waverly Light and Power, 158

Westinghouse Electric Company, 159

Wisconsin Public Service Corp., 160

\section{ENVIRONMENT}

Air \& Waste Management Association (A\&WMA), 1

Alliance to Save Energy, The, 2

America Forest Foundation, 8

American Chemical Society, 5

American Council for an Energy-Efficient Economy (ACEEE), 7

American Geological Institute, 9

American Nuclear Society, 10

American Petroleum Institute, 11

American Water Works

Association, 15

American Wind Energy

Association, 16

Apple Computer, Inc., 17
Arizona Department of Commerce, Energy Office, 18

Aseptic Packaging Council, The, 19

Baltimore Gas and Electric Company (BGE), 21

Bronx Zoo/Wildlife Conservation Park, 23

Bullfrog Films, 24

California Energy Commission, 25

Center for Renewable Energy \& Sustainable Technology (CREST), 28

Channing L. Bete Publishing Co., Inc., 29

Charles Edison Fund, 30

Chlorine Chemistry Council, The (CCC), 31

City Public Service (CPS), 32

Cobblestone Publishing, 34

Colorado School of Mines, 35

Consumer Aerosol Products

Council, The, 36

Culver Publishing, 37

Dayton Power \& Light Company, 38

Disney Educational Productions, 40 
E2: Environment \& Education, 41

Earth Foundation, 42

East Ohio Gas, 43

Edison Electric Institute (EEI), 44

Educational Development

Specialists, 46

Energy Source Education Council, 47

Enterprise for Education, Inc., 48

Environmental Hazards

Management Institute (EHMI), 49

EV Media, 50

Florida Energy Office, 53

Florida Power \& Light Company, 54

Florida Solar Energy Center (FSEC), 55

Foodservice \& Packaging Institute, Inc., 56

Frey Scientific, 57

General Atomics Sciences

Education Foundation, 58

Geothermal Education Office, 59

GPU Energy, 60

Hawaiian Electric Company, Inc., 61
Houston Lighting \& Power

Company, 62

Indiana Department of Education, 65

Institute for Chemical Education, The (ICE), 66

Integrated Waste Services

Association, 67

Jacksonville Electric.Authority (JEA), 68

Johnson Controls, Inc., 69

Keep America Beautiful, Inc., 70

Kids for A Clean Environment (Kids F.A.C.E.), 71

Kissimmee Utility Authority (KUA), 72

Learning Works, The, 73

Midwest Renewable Energy Association, 74

National Aeronautics and Space Administration (NASA), 77

National Arbor Day Foundation, 78

National Association of

Conservation Districts (NACD), 79

National Cotton Council of America, 81

National Energy Education

Development (NEED), 82 
National Energy Foundation

(NEF), 83

National Geographic Society, 84

National Propane Gas Association, 88

National Science Foundation, 90

National Science Resources Center (NSRC), 91

National Science Teachers

Association, 92

National Wildlife Federation, 93

Natural Gas Supply Association (NGSA), 95

NoodleHead Network, The, 97

Northeast Sustainable Energy

Association (NESEA), 98

Northeast Utilities, 99

Northern Indiana Public Service

Company, 100

Northern States Power Company, 101

Nuclear Energy Institute, 102

Nuclear Information and Resource Service, 103

OG\&E Electric Services, 104

Pacific Gas \& Electric Company, 108
Plastic Bag Association, 110

Polystyrene Packaging Council, 111

PP\&L, Inc., 109

Procter \& Gamble Company, 112

Railroad Commission of Texas, 114

Renew America, 116

Safe Energy Communication Council, 117

Science Screen Report, 118

Science Service, 119

Shell Oil Company, 120

SME, 121

Solar Now, 124

Steel Recycling Institute, 125

Sugar Association, Inc., The, 126

Troll School and Library, 127

U.S. Consumer Information Center, 131

U.S. Department of Agriculture Forest Service, 132 
U.S. Department of Commerce

National Oceanic \&

Atmospheric

Administration (NOAA) 133

U.S. Department of Education

ERIC Clearinghouse for Science, Mathematics, and Environmental Education, 134

Office of Educational Research \& Improvement (OERI), 135

U.S. Department of Energy

Bioenergy Feedstock Development Program, 137

Bonneville Power Administration, 138

Carbon Dioxide Information Analysis Center (CDIAC), 139

Energy Efficiency and Renewable Energy Clearinghouse (EREC), 141

Federal Energy

Technology Center, 142

Los Alamos National Laboratory, 143

National Energy Information Center (NEIC), 145
Pacific Northwest

National Laboratory, 151

U.S. Department of the Interior

Bureau of Land

Management (BLM), 153

Minerals Management

Service (MMS), 154

U.S. Environmental Protection Agency (EPA), 155

Union of Concerned Scientists, 128

University of Florida, 129

Videodiscovery, Inc., 156

Water Environment Federation, 157

Waverly Light and Power, 158

Westinghouse Electric Company, 159

Wisconsin Public Service Corp., 160

\section{GEOSCIENCES/EARTH \\ SCIENCES}

Air \& Waste Management Association (A\&WMA), 1

America Forest Foundation, 8

American Geological Institute, 9

American Petroleum Institute, 11

Bullfrog Films, 24 
California Foundation for

Agriculture in the Classroom, 26

Charles Edison Fund, 30

Cobblestone Publishing, 34

Colorado School of Mines, 35

Consumer Aerosol Products

Council, The, 36

Denver Earth Science Project, 39

Disney Educational Productions, 40

East Ohio Gas, 43

Educational Development Specialists, 46

Enterprise for Education, Inc., 48

Foodservice \& Packaging Institute, Inc., 56

Frey Scientific, 57

Geothermal Education Office, 59

GPU Energy, 60

Integrated Waste Services

Association, 67

Jacksonville Electric Authority (JEA), 68

Learning Works, The, 73

Mineral Information Institute (MII), 75
- National Aeronautics and Space

Administration (NASA), 77

National Energy Education

I Development (NEED), 82

I National Energy Foundation (NEF), 83

National Geographic Society, 84

National Science Resources Center (NSRC), 91

National Science Teachers

Association, 92

National Wildlife Federation, 93

New York State Geological

Survey/State Museum, 96

Northern Indiana Public Service

Company, 100

Oklahoma Energy Resources

Board, 106

PP\&L, Inc., 109

Railroad Commission of Texas, 114

Science Screen Report, 118

Science Service, 119

SME, 121

Troll School and Library, 127 
U.S. Department of Commerce

National Oceanic \&

Atmospheric

Administration (NOAA), 133

\section{U.S. Department of Education}

ERIC Clearinghouse for Science, Mathematics, and Environmental Education, 134

Office of Educational Research \& Improvement (OERI), 135

U.S. Department of Energy

Carbon Dioxide Information Analysis

Center (CDIAC), 139

Energy Efficiency and Renewable Energy Clearinghouse (EREC), 141

U.S. Department of the Interior

Minerals Management Service (MMS), 154

Videodiscovery, Inc., 156

\section{NATURAL GAS}

American Petroleum Institute, 11
Baltimore Gas and Electric

Company (BGE), 21

California Energy Commission, 25

Channing L. Bete Publishing Co., Inc., 29

Charles Edison Fund, 30

City Public Service (CPS), 32

Culver Publishing, 37

Dayton Power \& Light Company, 38

Denver Earth Science Project, 39

E2: Environment \& Education, 41

East Ohio Gas, 43

Edison Electric Institute (EEI), 44

Educational Development

Specialists, 46

Energy Source Education Council, 47

Enterprise for Education, Inc., 48

Florida Energy Office, 53

GPU Energy, 60

Independent Petroleum Association of America, 64

Indiana Department of Education, 65

Jacksonville Electric Authority (JEA), 68 
Kissimmee Utility Authority (KUA), 72

National Energy Education Development (NEED), 82

National Energy Foundation (NEF), 83

National Geographic Society, 84

National Science Foundation, 90

National Science Teachers

Association, 92

Natural Gas Supply Association (NGSA), 95

Natural Gas Vehicle Coalition, The, 94

Northern Indiana Public Service

Company, 100

Northern States Power Company, 101

Ohio Oil \& Gas Association, 105

Oklahoma Energy Resources

Board, 106

Pacific Gas \& Electric Company, 108

PP\&L, Inc., 109

Railroad Commission of Texas, 114
Shell Oil Company, 120

U.S. Department of Education

ERIC Clearinghouse for Science, Mathematics, and Environmental Education, 134

U.S. Department of Energy

Clean Cities Hotline, 140

Energy Efficiency and Renewable Energy Clearinghouse (EREC), 141

National Alternative Fuels Hotline, 144

National Energy Information Center (NEIC), 145

U.S. Department of the Interior Minerals Management Service (MMS), 154

Wisconsin Public Service Corp., 160

\section{NUCLEAR ENERGY}

American Chemical Society, 5

American Nuclear Society, 10

Baltimore Gas and Electric

Company (BGE), 21 
California Energy Commission, 25

Charles Edison Fund, 30

City Public Service (CPS), 32

E2: Environment \& Education, 41

Energy Source Education Council, 47

Enterprise for Education, Inc., 48

Florida Power \& Light Company, 54

Frey Scientific, 57

General Atomics Sciences

Education Foundation, 58

GPU Energy, 60

Houston Lighting \& Power

Company, 62

Indiana Department of Education, 65

National Energy Education Development (NEED), 82

National Energy Foundation (NEF), 83

National Geographic Society, 84

National Science Foundation, 90

Northeast Utilities, 99

Northern Indiana Public Service Company, 100
Northern States Power Company, 101

Nuclear Energy Institute, 102

Nuclear Information and Resource Service, 103

Omaha Public Power District, 107

PP\&L, Inc., 109

Radon Group, Ltd., The, 113

Safe Energy Communication Council, 117

Science Screen Report, 118

Solar Now, 124

U.S. Department of Education

ERIC Clearinghouse for Science, Mathematics, and Environmental Education, 134

\section{U.S. Department of Energy}

Los Alamos National

Laboratory, 143

National Energy

Information Center

(NEIC), 145

Office of Nuclear Energy, Science and Technology, 149

Office of Scientific and Technical Information (OSTI), 150 
Union of Concerned Scientists, 128

Westinghouse Electric Company, 159

Wisconsin Public Service Corp., 160

\section{PETROLEUM}

American Chemical Society, 5

American Geological Institute, 9

American Petroleum Institute, 11

American Plastics Council, 12

BP America, 22

California Energy Commission, 25

Charles Edison Fund, 30

Colorado School of Mines, 35

Denver Earth Science Project, 39

E2: Environment \& Education, 41

Earth Foundation, 42

Educational Development

Specialists, 46

Energy Source Education Council, 47

Enterprise for Education, Inc., 48

Environmental Hazards

Management Institute (EHMI), 49

Exxon Company, U.S.A., 51
GPU Energy, 60

Independent Petroleum Association of America, 64

Indiana Department of Education, 65

Jacksonville Electric Authority (JEA), 68

Mineral Information Institute (MII), 75

National Energy Education

Development (NEED), 82

National Energy Foundation (NEF), 83

National Geographic Society, 84

National Science Teachers

Association, 92

New York State Geological

Survey/State Museum, 96

Ohio Oil \& Gas Association, 105

Oklahoma Energy Resources Board, 106

PP\&L, Inc., 109

Railroad Commission of Texas, 114

Shell Oil Company, 120

U.S. Department of Agriculture

Forest Service, 132 


\section{U.S. Department of Education}

ERIC Clearinghouse for Science, Mathematics, and Environmental Education, 134

U.S. Department of Energy

National Energy

Information Center (NEIC), 145

U.S. Department of the Interior

Bureau of Land

Management (BLM), 153

Minerals Management

Service (MMS), 154

\section{RECYCLING}

Air \& Waste Management Association (A\&WMA), 1

Aluminum Association, Inc., The, 3

America Forest Foundation, 8

American Chemical Society, 5

American Petroleum Institute, 11

American Plastics Council, 12

Apple Computer, Inc., 17

Aseptic Packaging Council, The, 19

Bronx Zoo/Wildlife Conservation Park, 23
I Bullfrog Films, 24

Center for Renewable Energy \&

Sustainable Technology (CREST), 28

Channing L. Bete Publishing Co., Inc., 29

Charles Edison Fund, 30

Consumer Aerosol Products

Council, The, 36

Dayton Power \& Light Company, 38

Disney Educational Productions, 40

Educational Development

Specialists, 46

Enterprise for Education, Inc., 48

Environmental Hazards

Management Institute (EHMI), 49

Foodservice \& Packaging Institute, Inc., 56

Frey Scientific, 57

I GPU Energy, 60

Indiana Department of Education, 65

Integrated Waste Services

Association, 67

Jacksonville Electric Authority (JEA), 68 
Keep America Beautiful, Inc., 70

Learning Works, The, 73

National Corn Growers

Association, 80

National Energy Education Development (NEED), 82

National Energy Foundation (NEF), 83

National Geographic Society, 84

National Network of Energy and Environmental Education

Professionals, 87

National Science Resources Center (NSRC), 91

National Science Teachers

Association, 92

National Wildlife Federation, 93

NoodleHead Network, The, 97

Northeast Utilities, 99

Northern States Power Company, 101

OG\&E Electric Services, 104

Pacific Gas \& Electric Company, 108

Plastic Bag Association, 110

Polystyrene Packaging Council, 111

PP\&L, Inc., 109
Procter \& Gamble Company, 112

Renew America, 116

Solar Now, 124

Steel Recycling Institute, 125

U.S. Department of Education

ERIC Clearinghouse for Science, Mathematics, and Environmental Education, 134

\section{U.S. Department of Energy \\ Energy Efficiency and Renewable Energy Clearinghouse (EREC),} 141

\section{U.S. Environmental Protection} Agency (EPA), 155

University of Florida, 129

Wisconsin Public Service Corp., 160

\section{RENEWABLE ENERGY}

America Forest Foundation, 8

American Nuclear Society, 10

American Solar Energy Society, 14

American Wind Energy

Association, 16

Arizona Department of Commerce, Energy Office, 18 
Bronx Zoo/Wildlife Conservation Park, 23

\section{Bullfrog Films, 24}

California Energy Commission, 25

Center for Renewable Energy \& Sustainable Technology (CREST), 28

Charles Edison Fund, 30

Disney Educational Productions, 40

E2: Environment \& Education, 41

Educational Development Specialists, 46

Energy Source Education Council, 47

Enterprise for Education, Inc., 48

Florida Energy Office, 53

Florida Solar Energy Center (FSEC), 55

Frey Scientific, 57

General Atomics Sciences

Education Foundation, 58

Geothermal Education Office, 59

GPU Energy, 60

Houston Lighting \& Power

Company, 62
Indiana Department of Education,

I 65

Integrated Waste Services

Association, 67

Jacksonville Electric Authority (JEA), 68

Keep America Beautiful, Inc., 70

Midwest Renewable Energy

Association, 74

Minnesota Department of Public Service, 76

National Corn Growers

Association, 80

National Energy Education

Development (NEED), 82

National Energy Foundation

(NEF), 83

National Geographic Society, 84

National Hydropower Association, The, 85

- National Network of Energy and Environmental Education

Professionals, 87

I

I National Science Teachers

I Association, 92

Natural Gas Supply Association (NGSA), 95

Northeast Sustainable Energy Association (NESEA), 98 
Northern States Power Company, 101

Nuclear Information and Resource Service, 103

PP\&L, Inc., 109

Radon Group, Ltd., The, 113

Renew America, 116

Renewable Fuels Association, 115

Safe Energy Communication Council, 117

Science Screen Report, 118

Society of Automotive Engineers International, 122

Solar Energy Industries Association, 123

Solar Now, 124

U.S. Department of Education

ERIC Clearinghouse for Science, Mathematics, and Environmental Education, 134

U.S. Department of Energy

Bioenergy Feedstock Development Program, 137

Bonneville Power Administration, 138

Clean Cities Hotline, 140
Energy Efficiency and Renewable Energy Clearinghouse (EREC), 141

Federal Energy Technology Center, 142

Los Alamos National Laboratory, 143

National Alternative Fuels Hotline, 144

\section{National Energy}

Information Center (NEIC), 145

National Renewable Energy Laboratory, 147

Office of Scientific and Technical Information (OSTI), 150

\section{Pacific Northwest}

National Laboratory, 151

Western Area Power Administration, 152

U.S. Department of the Interior

Bureau of Land Management (BLM), 153

U.S. Environmental Protection Agency (EPA), 155

Union of Concerned Scientists, 128

Videodiscovery, Inc., 156 
Wisconsin Public Service Corp., 160

\section{WASTE MANAGEMENT}

Air \& Waste Management Association (A\&WMA), 1

America Forest Foundation, 8

American Chemical Society, 5

American Nuclear Society, 10

American Petroleum Institute, 11

American Plastics Council, 12

Aseptic Packaging Council, The, 19

Bullfrog Films, 24

Channing L. Bete Publishing Co., Inc., 29

Charles Edison Fund, 30

Educational Development

Specialists, 46

Environmental Hazards

Management Institute (EHMI), 49

Flexible Packaging Association, 52

Florida Power \& Light Company, 54

Foodservice \& Packaging Institute, Inc., 56
Integrated Waste Services

Association, 67

Keep America Beautiful, Inc., 70

National Energy Education

Development (NEED), 82

National Geographic Society, 84

National Science Teachers

Association, 92

Nuclear Information and Resource Service, 103

Plastic Bag Association, 110

PP\&L, Inc., 109

Science Screen Report, 118

Steel Recycling Institute, 125

U.S. Department of Education

ERIC Clearinghouse for Science, Mathematics, and Environmental Education, 134

\section{U.S. Department of Energy}

Energy Efficiency and Renewable Energy Clearinghouse (EREC), 141

National Low-Level Waste Management Program, 146 
Office of Civilian Radioactive Waste Management, 148

Pacific Northwest

National Laboratory, 151

U.S. Environmental Protection Agency (EPA), 155

Videodiscovery, Inc., 156

Water Environment Federation, 157

Westinghouse Electric Company, 159

\section{WATER}

Air \& Waste Management Association (A\&WMA), 1

American Chemical Society, 5

American Geological Institute, 9

American Water Works

Association, 15

Apple Computer, Inc., 17

Bullfrog Films, 24

Channing L. Bete Publishing Co., Inc., 29

Charles Edison Fund, 30

Chlorine Chemistry Council, The (CCC), 31

City Utilities of Springfield, 33

Colorado School of Mines, 35
Culver Publishing, 37

Dayton Power \& Light Company, 38

Denver Earth Science Project, 39

Disney Educational Productions, 40

Educational Development

Specialists, 46

Enterprise for Education, Inc., 48

Environmental Hazards

Management Institute (EHMI), 49

Frey Scientific, 57

Geothermal Education Office, 59

Indiana Department of Education, 65

Jacksonville Electric Authority

(JEA), 68

Learning Works, The, 73

National Association of

Conservation Districts (NACD), 79

National Energy Foundation

(NEF), 83

National Geographic Society, 84

National Hydropower Association, The, 85

National Science Teachers

Association, 92

National Wildlife Federation, 93 
Northern Indiana Public Service Company, 100

PP\&L, Inc., 109

Radon Group, Ltd., The, 113

Renew America, 116

Science Screen Report, 118.

U.S. Consumer Information Center, 131

U.S. Department of Agriculture

Forest Service, 132

U.S. Department of Commerce

National Oceanic \&

Atmospheric

Administration (NOAA), 133

U.S. Department of Education

ERIC Clearinghouse for Science, Mathematics, and Environmental Education, 134

U.S. Department of Energy

Bonneville Power

Administration, 138

Energy Efficiency and

Renewable Energy

Clearinghouse (EREC), 141

U.S. Environmental Protection Agency (EPA), 155
University of Illinois at UrbanaChampaign, 130

Videodiscovery, Inc., 156

Water Environment Federation, 157
I 